\title{
Effects of Salinity Stress on Chloroplast Structure and Function
}

\author{
Abdul Hameed ${ }^{1}$ (D), Muhammad Zaheer Ahmed ${ }^{1}$ (D), Tabassum Hussain ${ }^{1}$ (D) Irfan Aziz ${ }^{1}, \mathrm{Niaz}^{\mathrm{Ahmad}}{ }^{2,3}$ (D), $^{\text {, }}$ \\ Bilquees Gul ${ }^{1}$ and Brent L. Nielsen ${ }^{4, *(D)}$
}

1 Dr. M. Ajmal Khan Institute for Sustainable Halophyte Utilization, University of Karachi, Sindh 75270, Pakistan; ahameed@uok.edu.pk (A.H.); mzahmed@uok.edu.pk (M.Z.A.); thussain@uok.edu.pk (T.H.); irfanaziz@uok.edu.pk (I.A.); bilqueesgul@uok.edu.pk (B.G.)

2 Agricultural Biotechnology Division, National Institute for Biotechnology \& Genetic Engineering (NIBGE), Faisalabad 44000, Pakistan; niazbloch@yahoo.com

3 Department of Biotechnology, Pakistan Institute of Engineering and Applied Science (PIEAS), Islamabad 44000, Pakistan

4 Department of Microbiology \& Molecular Biology, Brigham Young University, Provo, UT 84602, USA

* Correspondence: brentnielsen@byu.edu

check for updates

Citation: Hameed, A.; Ahmed, M.Z.; Hussain, T.; Aziz, I.; Ahmad, N.; Gul, B.; Nielsen, B.L. Effects of Salinity Stress on Chloroplast Structure and Function. Cells 2021, 10, 2023. https:// doi.org/10.3390/cells10082023

Academic Editor:

Suleyman Allakhverdiev

Received: 30 July 2021

Accepted: 5 August 2021

Published: 7 August 2021

Publisher's Note: MDPI stays neutral with regard to jurisdictional claims in published maps and institutional affiliations.

\section{Copyright: (C) 2021 by the authors.} Licensee MDPI, Basel, Switzerland. This article is an open access article distributed under the terms and conditions of the Creative Commons Attribution (CC BY) license (https:// creativecommons.org/licenses/by/ $4.0 /)$.

\begin{abstract}
Salinity is a growing problem affecting soils and agriculture in many parts of the world. The presence of salt in plant cells disrupts many basic metabolic processes, contributing to severe negative effects on plant development and growth. This review focuses on the effects of salinity on chloroplasts, including the structures and function of these organelles. Chloroplasts house various important biochemical reactions, including photosynthesis, most of which are considered essential for plant survival. Salinity can affect these reactions in a number of ways, for example, by changing the chloroplast size, number, lamellar organization, lipid and starch accumulation, and interfering with cross-membrane transportation. Research has shown that maintenance of the normal chloroplast physiology is necessary for the survival of the entire plant. Many plant species have evolved different mechanisms to withstand the harmful effects of salt-induced toxicity on their chloroplasts and its machinery. The differences depend on the plant species and growth stage and can be quite different between salt-sensitive (glycophyte) and salt-tolerant (halophyte) plants. Salt stress tolerance is a complex trait, and many aspects of salt tolerance in plants are not entirely clear yet. In this review, we discuss the different mechanisms of salt stress tolerance in plants with a special focus on chloroplast structure and its functions, including the underlying differences between glycophytes and halophytes.
\end{abstract}

Keywords: salinity stress; photosynthesis; chloroplast; plastid; osmolytes; osmotic adjustment

\section{Introduction}

Soil quality in many parts of the U.S. and worldwide is susceptible to a variety of stresses, including drought, temperature, deterioration due to erosion and other factors, and increasing salinity due to evaporation and/or irrigation practices. At the same time the human population is growing and in many regions high-quality agricultural land is decreasing due to the expansion of urban areas [1].

Salinity is inhibitory to the growth and development of many plants, including most crops [2-5]. It affects all cellular processes, including disruption of cellular homeostasis, impairment of photosynthesis, mRNA processing, transcription, protein synthesis, disruption of energy metabolisms, amino acid biosynthesis as well as lipid metabolism [6-10]. In response to increasing salt, plant cells activate specific $\mathrm{Na}^{+}$and $\mathrm{Cl}^{-}$ion transporters and adjust the accumulation of cytosolic $\mathrm{K}^{+}$[10-12]. Plant cells must also undergo osmotic adjustment, which is accomplished in many ways, including the production of organic osmolytes such as glycine betaine, proline, some sugars, and polyamines, of which most are synthesized in the chloroplast $[3,10]$. 
Chloroplasts belong to a family of cellular organelles commonly found in plant and algal cells known as plastids. Green plastids-chloroplasts-are the site where atmospheric $\mathrm{CO}_{2}$ fixation occurs through a series of biochemical reactions called the Calvin-Benson cycle by utilizing the energy produced by the light reactions of photosynthesis [13]. Elevated salinity levels affect many cellular processes, including photosynthesis, the major function of chloroplasts. The presence of salt in the soil may cause both osmotic and ionic stresses [14], which may hinder photosynthesis through the diffusional (stomatal, mesophyll and boundary layer resistance to $\mathrm{CO}_{2}$ ) and/or non-diffusional (photochemical and biochemical) limitations of carbon fixation [6,15-20]. Salinity exposure is also known to decrease the chlorophyll content in many plants [21,22]. However, salt-resistant plants, particularly those with a $\mathrm{C}_{4}$ mechanism, may overcome the inhibitory effect of salinity on $\mathrm{CO}_{2}$ fixation more effectively $[6,23]$.

In general, when plants are exposed to salt stress, the very first response is osmotic shock followed by induction of stomatal closure. Stomatal closure, in turn, limits photosynthetic capacity by the restriction of $\mathrm{CO}_{2}$ supply. However, research has shown that increasing the external $\mathrm{CO}_{2}$ concentration under salt stress did not lead to an increase in photosynthesis rates in many cases. This observation suggests the involvement of some non-stomatal components in photosynthesis reduction under salinity, such as overproduction of reactive oxygen species (ROS) and the depletion of $\mathrm{K}^{+}$inside plant cells due to the accumulation of $\mathrm{Na}^{+}[24,25]$. This results in the disruption of ionic homeostasis in chloroplasts.

Besides $\mathrm{CO}_{2}$ fixation, thylakoid reactions are also affected by salinity $[6,18,26]$. The most commonly studied parameters in this context are the maximum quantum efficiency of the PSII reaction centers $\left(F_{v} / F_{m}\right)$, quantum efficiency of PSII (ФPSII), non-photochemical quenching (NPQ), photochemical quenching (qP) and electron transport rate (ETR), which defines the overall performance of plants under different stresses [27]. Salt-resistant plants are known to possess resilient thylakoid reactions to overcome salinity effects such as photodamage [28] and protection of the reaction centers [29]. This may include protective mechanisms such as cyclic electron flow, photorespiration in $\mathrm{C}_{3}$ plants and regulation of NPQ $[18,30] . \mathrm{CO}_{2}$ fixation and thylakoid reactions of photosynthesis take place in thylakoids and the stroma of the chloroplast, providing the essential carbon skeleton for growth, energy for driving various metabolic reactions as well as the biosynthesis of different metabolites. Salt-induced toxicity negatively affects all these processes, resulting in poor plant growth and reduction in yield. Chloroplasts are also major reactive oxygen species (ROS) production sites at the reaction centers of PSII and PSI, where charge separation occurs, and the electron transport chain (ETC) from PSII to PSI are highly sensitive to salt-induced toxicity under which ROS production is further increased [31]. Higher concentrations of ROS cause oxidative damage to membranes, lipids, nucleic acids, proteins and some photosynthetic enzymes, resulting in reduced $\mathrm{CO}_{2}$ fixation, slower plant growth and consequently low crop yields. The ROS-scavenging system includes both enzymatic and non-enzymatic antioxidants that prevent oxidative damage. Therefore, manipulation of the components of this system holds great implications for improving the photosynthetic rates under salt stress in crop plants. This has been tested by overexpression of $\mathrm{Cu} / \mathrm{Zn}$ superoxide dismutase (SOD) in the chloroplasts of tobacco [32,33] and Chinese cabbage [34]. Since chloroplasts are largely under the control of nuclear gene expression for growth and metabolic activities, chloroplasts have evolved a sophisticated signaling network to coordinate with the nucleus to control gene expression and maintain the balanced expression of genes in the two compartments. Chloroplasts also act as global sensors relaying changes in their own developmental status as well as in the environmental conditions, including light intensity and stresses to the nucleus. As a result, the nucleus adjusts the expression of its genes to ensure optimal plant performance under changing environmental conditions [35]. Until recently, this chloroplast-nucleus communication has been largely viewed as bilateral, ignoring the pivotal role of chloroplasts in adjusting gene expression and metabolic processes that affect photosynthesis and ultimately crop yields. 
In this review, we discuss the effect of salt stress on chloroplasts, their structures, and various biochemical reactions occurring in them. We also compare the differences in how chloroplasts of glycophytes and halophytes respond to salinity stress.

\section{Effects of Salinity on Chloroplast Ultrastructure}

\subsection{Changes in Chloroplast Structure in Plants}

Chloroplasts are roughly 1-2 $\mu \mathrm{m}$ thick and 5-7 $\mu \mathrm{m}$ in diameter. They are enclosed in a chloroplast envelope, which consists of a double membrane with outer and inner layers; the space in between is called the intermembrane space. A third, internal membrane, extensively folded and characterized by the presence of closed disks (or thylakoids), is known as the thylakoid membrane. In higher plants, the thylakoids are arranged in tight stacks called grana. Grana are connected by stromal lamellae extended from one granum through the stroma into a neighboring granum. The thylakoid membrane envelops a central aqueous region known as the thylakoid lumen. The space between the inner membrane and the thylakoid membrane is filled with stroma, a matrix containing dissolved enzymes, starch granules and copies of the chloroplast genome [36].

Several changes have been associated with chloroplast structure in response to environmental factors and the availability of water and minerals [37]. These include modifications in the lamellar organization, resulting in chloroplast shrinkage [37], swelling of chloroplast lamellae and an unrecognizable grana structure under highly saline conditions [38]. Some plants, such as Atriplex spp., may undergo lipid deposition to counter the harmful effects of salt-induced toxicity $[39,40]$. In some instances, starch accumulation under high salinity has also been reported, such as in chloroplasts of wheat cultivars, which was related to damage to the sucrose-phosphate synthase in the cytosol, triggering the triose-phosphate pathway towards starch synthesis [41]. Changes in the ionic composition of starch-degrading enzymes may also be linked with excessive starch deposition [42]. Under saline conditions, reactions involving starch and sucrose biosynthesis are also known to be regulated by changes in the orthophosphate concentration $[43,44]$. Stress-induced destruction of the chloroplast envelope and an increase in the numbers of plastoglobuli in thylakoid membranes have also been reported in cucumber leaves [45]. Accumulation of starch grains in the chloroplasts of Thellungiella and tobacco plants is known to play an important role as osmotica in maintaining the structural integrity of the chloroplasts [46].

\subsection{Changes in Ultrastructure of Chloroplasts in Glycophytes and Halophytes}

Salt stress-induced alterations in the structure of chloroplasts or thylakoid membranes have been extensively examined in various salt-sensitive plants $[47,48]$ as well as in facultative halophytes [49]. Swelling of thylakoids under salt stress ( 200 mM NaCl) was reported in rice [50]. However, recent 3D analysis confirmed that rice chloroplasts became spherical under salt stress without any changes in the overall chloroplast volume [51]. Contrasting observations regarding chloroplast volume have been reported among different species. For example, chloroplasts of salt-sensitive cultivars of wheat exhibited an increase in volume possibly due to changes in the ionic composition of the stroma [42]. Spinach chloroplasts showed a decrease in volume with concomitant changes in light-scattering during electron transport [47]. Arabidopsis seedlings grown in the presence of salt also exhibited swollen chloroplasts with less developed granum structures [41]. Changes in the thylakoid ultrastructure of potato [52] and maize [53] under salinity have been previously related to perturbed ion homeostasis in chloroplasts.

In the case of halophytes, salt entry into the chloroplast stroma may be critical for grana formation and photosystem II activity, as halophytes have been reported to accumulate more chloride $\left(\mathrm{Cl}^{-}\right)$than glycophytes and use sodium $\left(\mathrm{Na}^{+}\right)$in different functions [54]. Chloroplast swelling of Atriplex leaf cells at $345 \mathrm{mM} \mathrm{NaCl}$ appeared to be a likely result of the osmotic effect of salinity while few changes were reported in the chloroplasts of hair cells [40]. Similarly, distinct thylakoid swelling in Thellungiella under saline conditions $(400 \mathrm{mM} \mathrm{NaCl})$ was attributed to the disturbance in osmotic equilibrium [54]. Other 
notable changes in halophyte chloroplasts include the formation of 'slim spindle-shaped' grana with a clear stromal matrix in the halophyte Kandelia candel at $400 \mathrm{mM}$ and increases in the plastoglobuli numbers at $600 \mathrm{mM} \mathrm{NaCl}$ with intact grana thylakoids [49]. In Bruguiera parviflora, no major alterations in the structural integrity or absorption characteristics of the thylakoid membranes were noted at $400 \mathrm{mM} \mathrm{NaCl}$; however, a reduction in antenna size, as well as cytochrome (Cyt) $f$ and Cyt $b_{6}$ were observed [55].

\subsection{Changes in the Chloroplast Ultrastructure of $\mathrm{C}_{4}$ Plants}

Plants with $\mathrm{C}_{4}$ photosynthesis possess chloroplasts both in the bundle sheath cell (BSC) and the mesophyll cell (MC). Both of these chloroplast types, BSC and MC, have been reported to respond differently to salt stress. $\mathrm{C}_{4}$ plants are further divided into three subtypes, namely, NADP-malic enzyme (NADP-ME), NAD-malic enzyme (NAD-ME) and phosphoenolpyruvate carboxykinase (PCK) types, with peculiar leaf anatomical characteristics [56]. The NADP-ME type 4 species showed little damage to BSC chloroplasts compared to MC chloroplasts [57]. The BSC chloroplasts showed the development of grana when exposed to salt stress [53,58]. On the other hand, thylakoid swelling and disruption of envelopes in MC chloroplasts of both the NAD-ME and PCK types were observed under saline conditions [57]. It has also been reported that exposure to salinity enhanced granal development in BSC chloroplasts and appressed thylakoid density [57]. However, granal development in the NAD-ME and PCK type species is not as pronounced as in the NADP-ME type species. It is believed that granal development in BSC chloroplasts could compensate for the loss of PSII activity in MC chloroplasts under salt stress [53]. In glycophyte plants of the NADP-ME and NAD-ME subtypes, salt stress causes grana unstacking in MC chloroplasts but induces grana formation in BSC chloroplasts. Interestingly, in halophytes of the same subtypes, the grana are constitutively present in BSC chloroplasts and the unstacking of grana is absent in MC chloroplasts [53,58].

\subsection{Effects of Salinity on Chloroplast Multiplication}

Although the number of chloroplasts per leaf cell varies from a few to hundreds [59], they may occupy more than half of the cytoplasm volume in mesophyll cells [60]. Salinity may increase the number of chloroplasts per cell, e.g., in spinach, sugar beet [61], wheat [62], Arabidopsis [63] and Thellungiella halophila [46]. Bose et al. [29] proposed that halophytes have a greater capacity to increase chloroplast number than glycophytes under salinity, which may help in storing $\mathrm{Na}^{+}$and $\mathrm{Cl}^{-}$without compromising photosynthesis [63]. Increases in succulence help in cell expansion and thus enable housing more chloroplasts [29]. Halophytes can accumulate over 20-fold higher $\mathrm{Na}^{+}$levels in chloroplasts compared to glycophytes [63-68]. In addition to compensating for reduced photosynthesis, increases in chloroplast number may also contribute to increased energy demands for osmotic adjustment and ion homeostasis under salinity [29]. Although information about the genes involved in binary fission of chloroplasts is plentiful [68-70], the detailed effects of salinity on the mechanism/regulation of chloroplast multiplication, particularly among halophytes and glycophytes, are limited.

\section{Effects of Salinity on Transport across Chloroplast Membranes}

Most of the nuclear-encoded proteins destined for chloroplasts are synthesized as 'cytosolic preproteins' and imported by a major pathway consisting of transmembrane protein complexes or channels, 'Toc' (translocons on outer chloroplast) and 'Tic' (translocons on inner chloroplast). The 'Toc' transmembrane channels import larger molecules (including nuclear-encoded proteins) while the 'Tic' complexes are more restrictive, with transport limited to targeted proteins [71]. Located at the interface between the stroma and the cytosol, the envelope is also the site for the transport and exchange of ions and metabolites required for the integration of the plastid metabolism within the plant cell. In general, chloroplasts harbor three types of membranes and each of them is equipped with a unique set of ion channels and transporters enabling the transport of nutrients, solutes, and 
metabolites in and out of it. This is achieved by coordinated regulation of a variety of transport systems located in chloroplast membranes, such as porins, solute channels, ion-specific cation/anion channels and various primary and secondary active transport systems [29].

\subsection{Protein Transport across Chloroplast Membranes}

The chloroplast proteome comprises 3000 different proteins, including components of the photosynthetic apparatus, which are highly abundant [72]. Most chloroplast proteins are nuclear-encoded, synthesized in the cytosol, and their import is mediated by multiprotein complexes in the envelope membranes that surround each organelle. The Toc complex mediates client protein recognition and early stages of the import. The Toc apparatus is regulated by the ubiquitin-proteasome system (UPS) in a process controlled by the envelope-localized ubiquitin E3 ligase SUPPRESSOR OF PPI1 LOCUS1 (SP1) [73]. Salinity stress depletes the Toc apparatus by enhancing the expression of SP1, which in turn may result in the suppression of photosynthesis activity [74].

\subsection{Ion Transport across Chloroplast Membranes}

The proper ionic $\left(\mathrm{K}^{+}, \mathrm{Na}^{+}, \mathrm{Cl}^{-}\right)$balance is essential to control chloroplast volume [73]. For example, $\mathrm{Cl}^{-}$influx from stroma to the lumen is required for thylakoid swelling, while lumen shrinkage is due to $\mathrm{K}^{+}$(or $\mathrm{Na}^{+}$) efflux from the lumen to the stroma [75]. The outer membrane is not freely permeable to ions as some porins (OEP23, OEP37) are reported to have high cation selectivity [76], although information regarding their role in plant salt tolerance is lacking. The literature reports several nucleus-encoded candidate ion channels and transporters that regulate $\mathrm{Na}^{+}, \mathrm{K}^{+}$and $\mathrm{Cl}^{-}$transport through the chloroplast envelope and thylakoid membranes [75-79]. A several-fold increased $\mathrm{Na}^{+}$and $\mathrm{Cl}^{-}$concentration in barley chloroplasts under salt stress has been reported [76] Slabu et al. [79] reported that salt-induced damage in broad bean chloroplasts is due to the accumulation of $\mathrm{Na}^{+}$and not of $\mathrm{Cl}^{-}$or $\mathrm{K}^{+}$. In contrast, salt toxicity and inhibition of photosynthesis in soybean were found associated with the hyperaccumulation of $\mathrm{Cl}^{-}$but not that of $\mathrm{Na}^{+}$in chloroplasts $[80,81]$.

\subsection{Chloroplast Trafficking of Ions in Glycophytes vs. Halophytes}

Halophytes preferentially accumulate $\sim 20$-fold higher $\mathrm{Na}^{+}$levels than glycophytes $[64,65,67]$. This high ion level is known to have some effect on chloroplast functions [63,64,67], especially in the case of CAM and $\mathrm{C}_{4}$ plants [81]. The $\mathrm{Na}^{+}$contribution in the transport of pyruvate [82,83], ascorbate [84] and phosphate [85] into chloroplasts has been reported but the effect of salt stress on transport requires further elaboration. Salt stress induces $\mathrm{K}^{+}$loss from chloroplasts in both glycophytes and halophytes. Chloroplasts isolated from halophytes revealed better tolerance to high $\mathrm{Na}^{+}\left(100 \mathrm{mmol} \mathrm{L}^{-1} \mathrm{Na}^{+}\right)$and low $\mathrm{K}^{+}\left(50 \mathrm{mmol} \mathrm{L}^{-1}\right.$ $\mathrm{K}^{+}$) in the cytosol than chloroplasts of glycophytes [86]. Likewise, halophytes accumulate more $\mathrm{Cl}^{-}$than glycophytes under low salt conditions $\left(\leq 1 \mathrm{mmol} \mathrm{L}{ }^{-1} \mathrm{Cl}^{-}\right)$, while at higher salinities some halophytes maintain steady $\mathrm{Cl}^{-}$concentrations, and others show a slight increase within the chloroplasts $[63,65]$. These findings indicate that halophytes have mechanisms to regulate the $\mathrm{Cl}^{-}$concentrations; however, the candidate transporters for $\mathrm{Cl}^{-}$regulation during salt stress remain uncharacterized.

\subsubsection{Aquaporins and Non-Selective ion Channels}

Aquaporins (PIP2;1, PIP2.3, PIP2;7, PIP1;3 and PIP1;2) are reported on the chloroplast membrane [77,78]. Expression of both PIP2;1 and PIP2;7 is altered by salinity [87]. Some aquaporins also have the ability to transport ions [88], but little is known about their function/regulation.

Non-selective ion channels include mechanosensitive channels (MSL2 and MSL3) that help reduce chloroplast swelling during hypo-osmotic conditions by releasing ions from 
the stroma [89]. In general, the ion selectivity of MSLs varies from non-selective to $\mathrm{Cl}^{-}, \mathrm{K}^{+}$, $\mathrm{Na}^{+}$or $\mathrm{Ca}^{2+}$ selective channels [75].

\subsection{2. $\mathrm{Na}^{+}, \mathrm{K}^{+}$and $\mathrm{Cl}^{-}$Transporters}

Sodium ions $\left(\mathrm{Na}^{+}\right)$can be transported into chloroplasts through an inner envelope membrane-localized $\mathrm{Na}^{+}$-dependent pyruvate transporter (BASS2) that is abundantly found in halophyte species compared to glycophytes [82]. Introduction of a halophyte BASS2 gene into glycophyte chloroplasts resulted in improved salt tolerance [83]. The inorganic phosphate transporters (thylakoid membrane-localized PHT4;1 and inner envelope localized PHT4;4 and PHT4;5) can use $\mathrm{Na}^{+}$or $\mathrm{H}^{+}$as a co-transporting ion [79], thereby changing the $\mathrm{Na}^{+}$concentration inside the chloroplasts. The existence of the $\mathrm{Na}^{+} / \mathrm{H}^{+}$antiporter (NhaD; hereafter NHD)-type transporters at the chloroplast membrane mediating $\mathrm{Na}^{+}$efflux from the stroma was also reported in a halophytic tree, Populus euphratica [82]. In Arabidopsis, salt stress did not alter the expression of NHD1 but silencing NHD1 resulted in high chloroplast $\mathrm{Na}^{+}$and poor growth and photosynthetic performance [67]. In contrast, analysis of Mesembryanthemum crystallinum (a halophyte) under salt stress showed an increase in NHD1 expression that resulted in higher $\mathrm{Na}^{+}$accumulation, indicating the involvement of $\mathrm{NHD1}$ in $\mathrm{Na}^{+}$import into the chloroplasts instead of $\mathrm{Na}^{+}$export [41]. Such opposite regulation of ion transport mechanisms requires further investigation for a more complete understanding of the salt tolerance mechanisms.

Two $\mathrm{K}^{+}$efflux antiporters (KEA1 and KEA2) located at the membrane of Arabidopsis have been suggested to function as $\mathrm{K}^{+} / \mathrm{H}^{+}$exchangers mediating $\mathrm{K}^{+}$export out of the stroma [90]. The Arabidopsis double loss-of-function kea1kea2 mutant showed better growth under salt stress as compared to the wild type, due to low $\mathrm{K}^{+}$efflux in the mutant resulting in increased $\mathrm{K}^{+}$retention as well as maintenance of $\mathrm{pH}$ in the stroma leading to improved photosynthetic performance and growth [91]. Arabidopsis KEA3, located in the thylakoid membrane, has been suggested to import $\mathrm{K}^{+}$into the lumen in exchange for $\mathrm{H}^{+}[91,92]$ and support in PSII quantum efficiency and $\mathrm{CO}_{2}$ assimilation under low light [93]; however, no information is available regarding KEA3 function during salt stress.

Electrophysiological studies have shown the existence of $\mathrm{Cl}^{-}$permeable channels in the chloroplast envelope and thylakoid membranes [75]. A bestrophin-like protein from Arabidopsis has been discovered and shown to alter PMF portioning by functioning as a voltage-dependent $\mathrm{Cl}^{-}$channel (AtVCCN1) on the thylakoid membrane [93]. The effects of salinity on chloroplasts are summarized in the model in Figure 1.

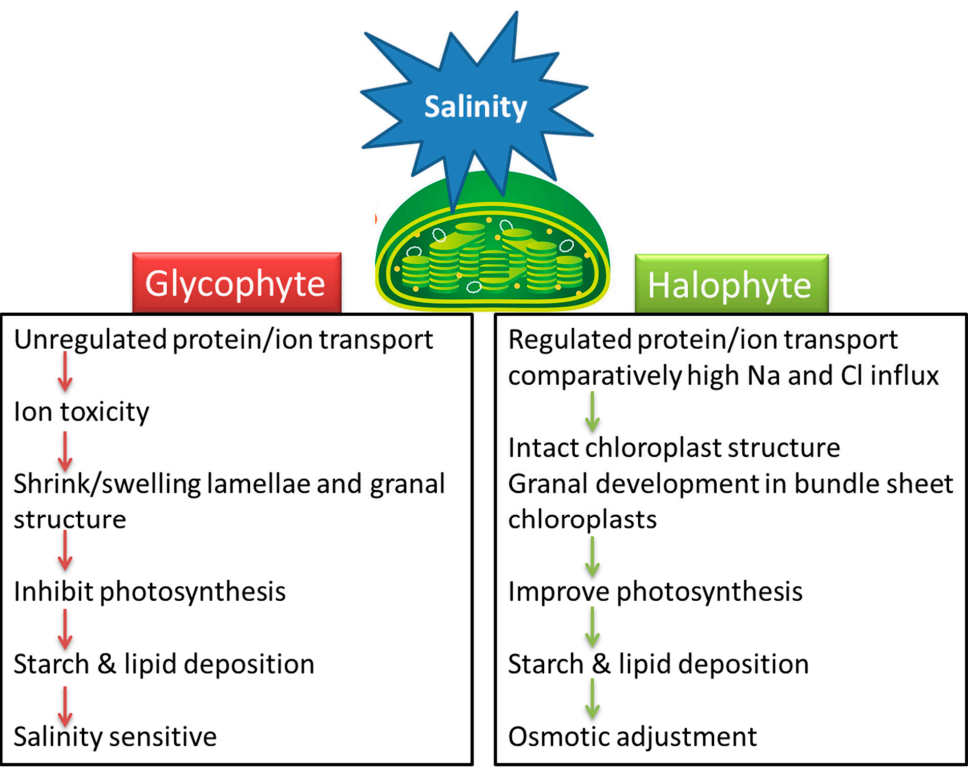

Figure 1. A model that summarizes the effects of salinity stress on chloroplasts in salt-sensitive (glycophyte) and salt-tolerant (halophyte) plants. 


\section{Effect of Salinity on Osmotic Adjustment in Chloroplasts}

\subsection{What Is Osmotic Adjustment and How Is It Achieved?}

Hyper-osmotic stress due to salinity is well-known in plants and bacteria and may cause disrupted cell metabolism, turgor loss and growth arrest. However, an adaptive mechanism for water retention exists among organisms under stressed environments whereby they increase their osmolality, a phenomenon commonly termed as 'osmotic adjustment' [94]. Increases in osmolality are achieved by either of the following three mechanisms: (1) micro-organisms, such as bacteria or yeast, accumulate a range of osmolytes or compatible solutes available from the external medium; (2) plants activate genes for de novo synthesis of organic osmolytes (so-called 'compatible solutes'), such as glycine betaine, proline, sugars, polyols, etc.; and (3) plants regulate ion flux across cellular membranes [20,95].

\subsection{Localization, Trafficking and Functions of Organic Osmolytes in Membrane-Bound Organelles}

Among the organic osmolytes, glycine betaine (GB), sugars (mannitol, sorbitol and trehalose), polyamines and proline are the most important and are accumulated under abiotic stresses and confer tolerance to cells without interfering with the cellular machinery of the plant [96]. Of these osmolytes metabolism of proline (PRO) depends upon two important enzymes, catalyzing its synthesis from glutamate in the cytoplasm or chloroplast and two enzymes catalyzing proline catabolism back to glutamate in the mitochondria along with an alternative pathway of its synthesis via ornithine [97]. During water deficit or physiological drought under salinity PRO is known to protect the photosynthetic apparatus as well as in cytokinin-dependent photorespiration [98]. Studies on other osmolytes suggest that sugar alcohols, such as sorbitol and mannitol, and quaternary ammonium compounds, such as GB and their precursors, are highly localized in chloroplasts $[99,100]$ and are somehow involved in protecting the photosystem (PSII) and membrane proteins against ROS under stress conditions $[95,101,102]$. The impairment of thylakoid membranes that results from salt stress may be alleviated by GB probably via protection and stabilization of the protein complexes as well as changes in lipid composition of the thylakoid membrane, thereby improving photosynthesis [102]. The accumulation of GB in higher concentrations in the chloroplasts of young leaves suggests that these are the main sites of its biosynthesis $[98,103]$ from where it is translocated to other plant parts via phloem [104]. Sugar alcohols and polyols, such as mannitol, sorbitol, etc., regulate osmotic balance by sequestering $\mathrm{Na}^{+}$in the vacuole or apoplast, thus protecting membranes against drought [105] and salt stress [106]. These osmolytes also scavenge ROS, particularly hydroxyl radicals that do not require high concentrations of osmolytes as needed for osmotic adjustment [97]. This leads to the conclusion that such compounds may be more important in 'osmoprotection' rather than 'osmotic adjustment'.

\subsection{Are Osmolytes Compatible for Osmotic Adjustment in Planta?}

The classical concept of osmotic adjustment via accumulation of organic solutes in non-halophilic organisms still prevails $[107,108]$ though it has been challenged by many physiologists $[97,109,110]$. A major shift in energy balance usually causes severe losses in growth yields of crop plants at the expense of other metabolic processes, raising the serious question of whether osmolytes are compatible in a real sense. Physiologists argue that conventional water retention under saline stress is not directly related to the contribution of organic solutes for many reasons. The first reason is the concentration of organic osmolytes, which seems to be too low compared to the inorganic solutes in cells. For instance, $3-10 \mathrm{mM}$ in plants contributes less than 3\% [111,112], while 120-150 mM glycine betaine (GB) in plants contributes $<50 \%$, often ranging between 10 and $30 \%$ of the total cell solutes [112]. Even if it is assumed that most of the osmolytes are contained in the cytosol and chloroplasts (collectively constituting 10-15\% of the cell volume) compared to a larger vacuolar fraction $(\sim 85 \%)$, this seems low given that $500-600 \mathrm{mM}$ concentrations of $\mathrm{Na}^{+}$alone exist within the vacuole [99]. Osmolyte concentrations (GB in particular) between 200 and $300 \mathrm{mM}$ may 
be sufficient to prevent cytoplasmic dehydration, thereby achieving osmotic adjustment. In some of the succulent halophytes (which accumulates up to $1000 \mathrm{mM} \mathrm{Na}^{+}$and $\mathrm{Cl}^{-}$), $\sim 200 \mathrm{mM}$ plant water GB was reported in Suaeda fruticosa and about $600 \mathrm{mM}$ in Haloxylon stocksii (sensu lato recurvum) under extreme saline conditions, which are exceptional as in other plants, including Halopyrum mucronatum and Atriplex stocksii (sensu lato griffithii), GB ranged between 100 and $150 \mathrm{mM}$ [113]. The second reason for not considering organic osmolytes as 'compatible' is the cost of their synthesis, which is too high. For instance, 30-109 molecules of ATP may be required for osmolyte synthesis compared to one molecule of ATP for one $\mathrm{K}^{+}$and two $\mathrm{Cl}^{-}$in bacteria [114], while plants require approximately 41 molecules of ATP for proline, 50 for glycine betaine and 52 for sucrose [115]. Thirdly, the synthesis of such organic solutes is very slow, often ranging from hours to many days while plants growing in water-stressed environments require rapid turgor recovery [102]. Moreover, salt-sensitive genotypes of many crop plants, e.g., rice, wheat, barley, etc., accumulate comparatively higher amounts of osmolytes than salt-tolerant varieties, which also creates ambiguity in the role of osmolytes in achieving osmotic adjustment $[81,109,116]$.

\subsection{Effects of Osmolytes on Organelles}

Although the osmotic adjustment is based on the notion that osmolytes should not interfere with other metabolic processes, some studies on exogenous application of osmolytes suggest their toxic effects on plant growth as well as cell organelles [116,117]. Application of some L-amino acids (L-proline, L-alanine, etc.) in millimolar concentrations caused growth inhibition in suspension cultures of Nicotiana silvestris [116]. In another instance, a disruptive effect of PRO on the ultrastructure of chloroplasts in Arabidopsis thaliana was linked to feedback inhibition of its synthesis due to over-reduction of the photosynthetic electron acceptor pools [117]. In the same plant, exogenously supplied PRO was thought to have increased the rates of mitochondrial electron transport, resulting in elevated levels of ROS causing subcellular damage [117]. On the contrary, endogenous PRO did not seem to have a negative impact on the ultrastructure of chloroplasts and mitochondria in transgenic tobacco, indicating that this level of PRO had no toxic effects [118]. Though the assumption of osmolyte toxicity is largely inconclusive, it seems that plants treated with exogenous application of osmotica may suffer from an 'overdose' compared to their endogenous levels. In fact, in certain cases, exogenous application (both foliar as well as through the rooting medium) of osmolytes such as GB, PRO, inositol, and mannitol have indicated stress alleviation in many plants $[29,119]$. Exogenous application of osmotica, such as GB, may also enhance the membrane integrity of chloroplasts and also increase PS II efficiency [97,98], suggesting an osmoprotective role. Experiments on exogenous application of osmolytes have intrigued geneticists to manipulate the biosynthetic pathway of compatible solutes to enhance salt tolerance as osmolyte accumulation is often controlled by only one gene [102].

\subsection{Possible Role of Osmolytes in Ion Regulation}

Although the published literature has contradicting reports on the role of osmotic adjustment via osmolytes for maintaining turgor, recent patch-clamp studies suggest that osmolytes may have a significant contribution in regulating ion transporters such as $\mathrm{K}^{+}$outward rectifying channels (KORs), though this requires further investigation [120]. Thus, ion regulation via osmolytes may prove to be an important aspect in conferring salt tolerance. In plants, $\mathrm{K}^{+}$appears to be the most abundant cation in the cytosol $(100-150 \mathrm{mM})$, which may account for osmotic adjustment [121], though under stressed conditions, the electrochemical gradients may lead to the loss of $\mathrm{K}^{+}$. In halophytes, $\mathrm{Na}^{+}$and $\mathrm{Cl}^{-}$seem to play a major role in osmotic adjustment [105]. Of these, $\mathrm{Na}^{+}$may enter the cell passively and could be used as a cheap osmoticum for maintaining cell turgor. Since $\mathrm{Na}^{+}$is toxic and may cause an imbalance in the cytosolic $\mathrm{K}^{+} / \mathrm{Na}^{+}$ratio and interferes with cell metabolism, its efficient sequestration in the vacuole is thus essential. Pumping of one mole of $\mathrm{Na}^{+}$ against the electrochemical gradient requires only $3.5 \mathrm{~mol}$ of ATP compared with $30-50 \mathrm{~mol}$ 
of ATP for one mole of organic osmolyte [115]. As mentioned above, some of the sugar alcohols and polyols regulate osmotic balance by sequestering $\mathrm{Na}^{+}$in the vacuole or apoplast. It appears that osmotic adjustment is collectively achieved by maintaining a balance between ion regulation, synthesis and accumulation of organic solutes, as well as maintenance of $\mathrm{K}^{+}$in the cytosol [122].

\section{Effects of Salinity on Function and Protection of Photosystems}

Under saline conditions, decreases in $\mathrm{CO}_{2}$ assimilation via the Calvin cycle accompany a decrease in photochemical electron sink, which in the presence of light impacts the functioning/efficiency of photosystems [31]. In some sensitive plants such as olives, decreases in the $F_{v} / F_{m}$ ratios indicate the incidence of photodamage under saline conditions [35]. Likewise, increases in salinity resulted in a gradual decrease in activities of PSI and PSII in four rice cultivars [123]. However, unchanged $F_{v} / F_{m}$ hints towards sustained PSII under saline conditions [124], such as in the Mangalamahsuri variety of rice [125]. PSII-mediated electron transport increased in low salinity followed by a decrease at high salinity in the halophyte Bruguiera parviflora [55]. In other instances, inhibition of de novo protein synthesis, especially of the D1 protein, indicated a lack of efficient PS II repair under saline conditions [2,126,127]. A compensation mechanism of PsbO protein induction has been observed in some studies to stabilize the PSII structure under salinity [128]. Among $C_{3}$ plants, salinity reportedly resulted in poor PSII function in glycophytes such as rice and Arabidopsis [41,129] but not in the halophyte Arthrocnemum macrostachyum $[130,131]$. Several tolerant species, including halophytes such as Sarcocornia fruticosa [132] and Atriplex centralasiatica [133], also employ the xanthophyll cycle for non-photochemical quenching that dissipates excess excitation energy of PSII in the form of heat as a 'first line of defense' [31,133], thus preventing the formation of potentially cytotoxic reactive ROS. The xanthophyll cycle enzyme violaxanthin de-epoxidase consumes NADPH, which if accumulated may cause the over-reduction of reaction centers, and thereby enhance ROS (especially superoxide) formation [134]. Hence, the timely induction of the xanthophyll cycle may protect plants under stressful conditions in multiple ways. Many halophytes are reported to exhibit reversible midday photoinhibition of PSII activity to limit excitation of the PSII reaction centers $[130,134]$. This mechanism also minimizes the possibility of ROS formation in salt-stressed plants under high light and is considered an important ecophysiological adaptation to salinity [31]. A decrease in the antennae size due to decreased chlorophyll content was also observed in Arthrocnemum macrostachyum to limit PSII excitation [132].

PSI is reportedly more stress-resistant than PSII and seems to impart salt tolerance by increasing cyclic electron flow to generate ATP while avoiding the accumulation of toxicreducing species [135-137]. Information about PSI in halophytes is scarce. PSI reaction center subunit IV protein (PsaE) was upregulated under salinity in wild halophytic rice Porteresia coarctata but not in conventional sensitive rice [137]. Similarly, salinity treatment caused an increase in PSI transcripts in M. crystallinum [138]. Formation of ATP via cyclic electron flow around PSI helped to prevent overaccumulation of $\mathrm{Na}^{+}$in chloroplasts of soybean [139].

Cultured plant cell lines have also been utilized to study salt-adapted tobacco cells [140,141]. Heterotrophic tobacco cells adapted to grow at $428 \mathrm{mM} \mathrm{NaCl}$ showed elevated levels of chlorophyll and lower levels of starch along with increased $\mathrm{CO}_{2}$ fixation, oxygen evolution and photorespiration, compared to unadapted cells [140]. This was coupled with higher levels of PS-I- and PS-II-associated proteins, including Rubisco. These cells were found to have acquired a significant level of salt-tolerant photosynthetic competence [140]. Further analysis showed that oxygen evolution and $\mathrm{CO}_{2}$ fixation were more resistant to inhibition by $\mathrm{NaCl}$ in the salt-adapted cells [141]. 


\section{Effects of Salinity on $\mathrm{CO}_{2}$ Assimilation Enzymes}

Information on the effects of salinity on chloroplast $\mathrm{CO}_{2}$ assimilation enzymes is limited among halophytes. Generally, $\mathrm{CO}_{2}$ assimilation reactions are considered more sensitive to salinity than photochemical reactions of photosynthesis [31]. Several studies have reported that salinity generally inhibits many enzymes of the Calvin cycle $[137,142,143]$.

Ribulose-1,5-bisphosphate carboxylase/oxygenase (Rubisco) is the key photosynthetic enzyme that catalyzes the fixation of atmospheric $\mathrm{CO}_{2}$ in plants during the Calvin cycle [144]. It is the most abundant protein in leaves that accounts for $30 \%\left(C_{4}\right.$ plants) to $50 \%$ ( $C_{3}$ plants) of total soluble protein in leaves [145]. In $C_{3}$ plants, it is localized in all chloroplasts while in $\mathrm{C}_{4}$ plants with Kranz anatomy, Rubisco is localized specifically in the bundle sheath but not mesophyll chloroplasts [65]. In single-cell $C_{4}$ species, Rubisco mRNA could be targeted to the proximal or central compartment of chloroplasts [146]. The activity of Rubisco was mostly examined by direct measurement of the enzyme activity or protein levels and measurement of its carboxylase activity $\left(\mathrm{V}_{\mathrm{cmax}}\right)$ [12]. Salinity exposure causes a decrease in Rubisco activity in most plant species regardless of $C_{3}$ or $C_{4}$ type $[19,146-148]$. In addition, the Rubisco levels also decreased under saline conditions in both halophytes and glycophytes. For example, salinity caused an inhibition ( $50 \%)$ of Rubisco activity in maize, a glycophyte, and in Atriplex spongiosa, a halophyte [149]. In some other instances, Rubisco activity was improved both in either low $[13,20]$ or high salinity [150]. Rubisco activity also depends on the function of a supporting enzyme, Rubisco activase, which revitalizes the active sites of Rubisco by removing inhibitory sugar phosphates $[151,152]$. The enhanced activity of Rubisco activase was found in rice as well as in many halophytes, such as S. salsa [143] and Thellungiella salsuginea, under saline conditions [153]. More efficient Rubisco activation was found in T. salsuginea compared to Arabidopsis thaliana [153].

Chloroplastic fructose-1,6-bisphosphatase is considered a metabolic control point of the Calvin cycle $[44,154]$. In vitro salt sensitivity of this enzyme was higher in saltsensitive rice (Oryza sativa cv. IR26) than its wild halophytic relative Porteresia coarctata [142]. However, the inhibitory effects of salinity could be reversed by preincubation of the enzyme with osmolytes (effectiveness order: polyol>sugars) [142], suggesting a lower level of in vivo inhibition of chloroplastic fructose 1,6-bisphosphatase under salinity in halophytes with higher amounts of osmolytes compared to glycophytes.

Phosphoenolpyruvate carboxylase (PEPC) is the key enzyme of $\mathrm{C}_{4}$ photosynthetic metabolism that catalyzes the $\beta$-carboxylation of phosphoenolpyruvate to form four-carbon acid oxaloacetate in the mesophyll cells $[144,155]$. It is considered more sensitive to salinity than Rubisco [149]. Furthermore, PEPC isolated from the halophyte Atriplex spongiosa was found more salt-sensitive in the in vitro studies than the one from the glycophyte maize [149]. Contrary to these observations, an increase in PEPC activity was reported in the halophyte Mesembryanthemum crystallinum [156] and in the $\mathrm{C}_{4}$ species Bienertia sinuspersici under salinity [157]. Increased PEPC activity helps concentrate $\mathrm{CO}_{2}$ around Rubisco and substantially reduces the incidence of photorespiration, a major cause for growth reduction and ROS formation under environmental stresses in plants.

Pyruvate orthophosphate dikinase is the rate-limiting enzyme of the $\mathrm{C}_{4}$ cycle that catalyzes a reversible reaction to regenerate the primary $\mathrm{CO}_{2}$ acceptor phosphoenolpyruvate (PEP) [158]. However, its role in $C_{3}$ plants is not fully understood [159]. Pyruvate orthophosphate dikinase is found in both chloroplasts and the cytoplasm irrespective of $\mathrm{C}_{3}$ or $\mathrm{C}_{4}$ types [160]. In $\mathrm{C}_{4}$ plants, it can comprise up to $10 \%$ of the total protein pool [161]. Interestingly, both isoforms are encoded by a single nuclear gene [162]. The labeling of the pyruvate orthophosphate dikinase protein was observed both in mesophyll and bundle sheath chloroplasts of kranz type $C_{4}$ plant maize, albeit with higher levels in the latter rather than the earlier-mentioned chloroplasts [163]. In single-cell $\mathrm{C}_{4}$ species, pyruvate orthophosphate dikinase mRNA could be targeted to the peripheral or distal compartment chloroplasts [146]. Information about the impacts of salinity on the abundance and activity of this enzyme is scant. Salinity caused an increase in pyruvate orthophosphate dikinase levels in both types of chloroplasts in maize [163]. These enzymes are widely studied and 
are important for the biochemical reactions of photosynthesis $[17,164,165]$. Induction of PEP activity would also help maintain $\mathrm{C}_{4}$ functionality under salinity stress and facilitate $\mathrm{CO}_{2}$ assimilation for biomass buildup and reduce photorespiration, as mentioned above.

\section{Effects on Salinity on the Gas Exchange Ecophysiology of Photosynthesis}

The effects of salinity on photosynthetic synthetic gas exchange, which eventually supports $\mathrm{CO}_{2}$ assimilation at the chloroplast level, varies not only among species but also depends on the magnitude of the salinity. For instance, the net $\mathrm{CO}_{2}$ assimilation rate $\left(P_{N}\right.$ or $A$ ) and stomatal conductance $(G s)$ in sugar beet improved under low (75 mM NaCl) salinity while high $(250 \mathrm{mM} \mathrm{NaCl})$ was inhibitory [166]. An increase in $P_{N}$ but not in transpiration $(E)$ under low salinity resulted in improved water-use efficiency (WUE) in sugar beet plants [166]. Salinity stress decreased the $P_{N}$ and Gs in wild-type wheat plants [24]. $P_{N}$ and Gs increased transiently at $200 \mathrm{mM} \mathrm{NaCl}$ in comparison to controls and $400 \mathrm{mM} \mathrm{NaCl}$ in the halophyte Sesuvium portulacastrum [167]. Similarly, in many other halophyte species, such as Arthrocnemum macrostachyum (in up to $510 \mathrm{mM} \mathrm{NaCl}$ ) [133] and Atriplex portulacoides (200 mM NaCl) [168], low to moderate salinity improved $P_{N}$. In contrast, salinity exposure resulted in decreased $P_{N}$ and $G s$ in the halophytes Panicum antidotale [20] and Aster tripolium [169]. Hence, impacts of salinity not only vary among glycophytes but also halophyte species. In many cases, decreased Gs improves the WUE of plants under stress conditions as a trade-off at the expense of $P_{N}$. For instance, in Sarcocornia fruticosa, increased WUE accompanied a decline in $P_{N}$ [170]. Similarly, many halophytes exhibit $C_{4}$ and CAM modes of photosynthetic $\mathrm{CO}_{2}$ assimilation, which not only reduce wastage of photosynthetic energy through photorespiration but also decrease the consequent $\mathrm{H}_{2} \mathrm{O}_{2}$ (a common ROS) production at the peroxisome level [31,171].

\section{Effects of Salinity on Chloroplast ROS Homeostasis}

Exposure of plants to salinity results in a reduction in $\mathrm{CO}_{2}$ assimilation rates, which in turn leads to the overreduction of PSII along with diversion of electrons to molecular oxygen, which generates reactive oxygen species (ROS), particularly singlet oxygen $[31,172,173]$. In photosynthesizing leaves, chloroplasts are the major site for ROS production during the daytime [174]. In $C_{3}$ plants, photorespiration resulting from the oxygenase activity of Rubisco in chloroplasts is another source of ROS generation in peroxisomes [31]. Salinity-induced stimulation of electron flow to molecular oxygen has been reported in several plant species [31,175,176]. Major ROS produced in chloroplasts include singlet oxygen $\left({ }^{1} \mathrm{O}_{2}\right)$, superoxide radical $\left(\mathrm{O}_{2}{ }^{\bullet-}\right)$, hydrogen peroxide $\left(\mathrm{H}_{2} \mathrm{O}_{2}\right)$ and hydroxyl radical $\left({ }^{\bullet} \mathrm{OH}\right)[31,173]$. Since detection of radicle-type ROS is difficult, most studies examine $\mathrm{H}_{2} \mathrm{O}_{2}$ (non-radicle ROS) formation following salinity exposure [31]. In addition, studies on ROS formation in isolated chloroplasts, particularly of halophytes, are very limited. Wiciarz et al. [153] reported that isolated thylakoids from a halophyte Thellungiella salsuginea produced higher $\mathrm{H}_{2} \mathrm{O}_{2}$ levels than the model glycophyte Arabidopsis thaliana. However, when both plant types were exposed to salt stress, even at the low level of $100 \mathrm{mM} \mathrm{NaCl}$, Arabidopsis produced a higher $\mathrm{H}_{2} \mathrm{O}_{2}$ than T. salsuginea and at a $300 \mathrm{mM} \mathrm{NaCl}$ concentration. Similarly, a substantially higher $\mathrm{H}_{2} \mathrm{O}_{2}$ level was observed in chloroplasts of wild salt-tolerant tomato Lycopersicon pennellii compared to chloroplasts of sensitive tomato L. esculentum under stress-free growth conditions. However, under $\mathrm{NaCl}$ stress, a decrease in $\mathrm{H}_{2} \mathrm{O}_{2}$ level was noted for wild tomato while the levels were increased in the sensitive species [171]. This indicates that halophyte species have efficient mechanisms to control the production of ROS or detoxify them compared to glycophytes, either through the dissipation of excess excitation energy to alternative electron sinks, such as the plastid terminal oxidase [29,172-180] (PTOX) or ROS-scavenging system [31,174]. Alternative electron sinks not only provide 'safety valves' for the efficient functioning of the photosynthetic machinery but also act as an 'avoidance' tool for control of ROS formation. Tightly regulated levels of ROS are now acknowledged as 'signals' for the regulation of different plant processes, including the defense/tolerance response of plants [3,99]. For 
instance, ROS modulate the function of some plasma membrane ion transporters, such as those regulating cytosolic $\mathrm{Na}^{+}$and $\mathrm{K}^{+}[177,181-185]$. Similarly, a ROS 'surge' in response to salinity exposure may also activate chloroplast retrograde signaling pathways [180].

In order to prevent oxidative damage due to ROS accumulation, chloroplasts possess many enzymatic and nonenzymatic antioxidants $[29,138,182,185]$. Key enzymatic antioxidants are superoxide dismutases (SOD), enzymes of the Foyer-Halliwell-Asada pathway (also known as the ascorbate-glutathione cycle), and glutathione peroxidase (GPX), whereas ascorbate and glutathione are common nonenzymatic antioxidants of chloroplasts (Figure 2) $[138,182,186]$. Antioxidants in various combinations play an important role to keep the levels of ROS in 'functionally useful' ranges for signaling various plant processes and stress responses [31]. The water-water cycle is among the key processes responsible for ROS homeostasis in chloroplasts and is essential for salinity tolerance (Figure 2) [31,187]. Ground state molecular oxygen $\left(\mathrm{O}_{2}\right)$ produced during photolysis of water in chloroplasts can accept electrons from excited photosystems, particularly the thylakoid membrane-bound primary electron acceptor of PSI to form $\mathrm{O}_{2}{ }^{--}$through a reaction called the Mehler reaction [188]. The acceptor side of the electron transport chain in PSII may also contribute to electron leakage to $\mathrm{O}_{2}$ to generate $\mathrm{O}_{2}{ }^{\bullet-}$. Thylakoid membranebound copper/zinc superoxide dismutase (Cu/Zn SOD) converts $\mathrm{O}_{2}{ }^{--}$into $\mathrm{H}_{2} \mathrm{O}_{2}$, which is finally reduced into the water by the action of thylakoid membrane-bound ascorbate peroxidase (tAPX), thus completing the 'water-water cycle' [189]. The Foyer-Halliwell-Asada pathway (also known as the ascorbate-glutathione cycle) in chloroplasts is an extension of the water-water cycle and involves quenching of ROS in chloroplasts by consuming $\mathrm{NADPH}$, which also contributes to relaxing the 'overreduction of photosystems' by providing NADP (the final electron acceptor of PSI), and thereby minimizing the chances of further ROS generation (Figure 2) $[167,190]$. In this pathway, the $\mathrm{H}_{2} \mathrm{O}_{2}$ generated from dismutation of $\mathrm{O}_{2}{ }^{--}$by SOD is neutralized into water by the action of stromal ascorbate peroxidase (APX) using ascorbate (AsA) as the electron donor. Oxidized ascorbate is recycled by monodehydroascorbate reductase (MDHAR) and/or dehydroascorbate reductase (DHAR). The latter consumes glutathione (GSH), which is finally recycled by the action of glutathione reductase (GR) that uses NADPH as an electron donor [167,190,191]. Often, an upregulation of enzymes involved in antioxidant processes is reported in chloroplasts under environmental stresses, with a higher magnitude of tolerance compared to sensitive species [31,181]. For instance, salinity exposure resulted in enhanced activities of SOD, APX and MDHAR in chloroplasts of halophytic wild tomato Lycopersicon pennellii compared to conventional sensitive tomato L. esculentum [172]. In addition, thioredoxin/peroxiredoxin (Trx/Prx) and glutathione peroxidase (GPX) also reportedly quenched salinity-induced excess $\mathrm{H}_{2} \mathrm{O}_{2}$ in chloroplasts [187]. Lipophilic tocopherol can protect chloroplast thylakoid membranes from oxidative damage [189]. The ${ }^{1} \mathrm{O}_{2}$ produced by PSII is mainly detoxified by carotenoids and tocopherols found in the chloroplast membranes [192]. Carotenoids detoxify ${ }^{1} \mathrm{O}_{2}$ not only through the xanthophyll cycle (NPQ) but also by direct quenching of ${ }^{1} \mathrm{O}_{2}$ [193]. However, some $\mathrm{C}_{4}$ plants, especially those with NADP-malic enzyme (NADPME) subtypes, lack PSII in their bundle sheath chloroplasts and hence supposedly lack ${ }^{1} \mathrm{O}_{2}$ production [194]. 


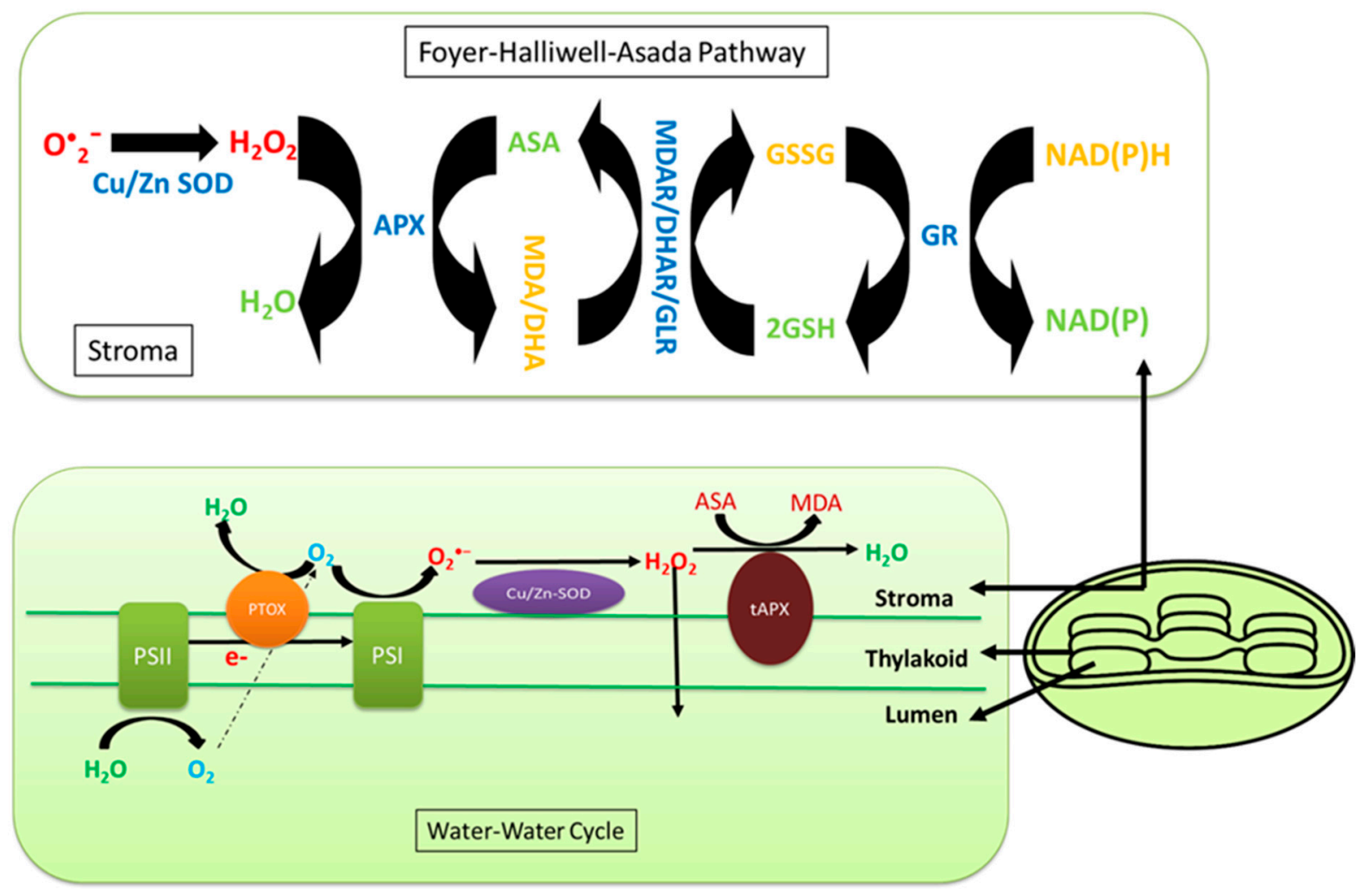

Figure 2. The Foyer-Halliwell-Asada pathway (also known as the ascorbate-glutathione cycle) and the water-water cycle are responsible to quench the superoxide radicles and hydrogen peroxide in the chloroplasts.

\section{Summary}

Soil salinity is one of the major challenges to the sustainable development of agriculture in different parts of the world. Salinity has detrimental effects on plant growth by imposing several constraints. For instance, salt-induced toxicity impairs the normal functioning of the organelles, such as chloroplasts-the green plastids - which house several important biochemical reactions, including photosynthesis. Chloroplast dysfunction as a result of various environmental stresses, including salinity, has been reported to have detrimental effects on plants [173]. Chloroplasts, in addition to being a site of various metabolic reactions, also act as global sensors to sense and communicate the developmental, operational and environmental changes to the nucleus.

Understanding the effect of salinity on chloroplast function and the response of various metabolic reactions to salt stress is necessary for the development of salt-tolerant crops. Little attention has been paid to how salinity affects chloroplasts and the stromal metabolic reactions. Salinity-related changes in the size, number, lamellar organization, lipid and starch accumulation, and trafficking across the chloroplast membrane are dependent on the plant species and its level of salt tolerance. Chloroplast swelling or alteration in thylakoid membranes of glycophytes may be linked with the ionic component of salinity while some halophytes are affected by the osmotic effect of high salinity (Figure 1). Most halophytes either maintain chloroplast structure or enhance grana development under salinity stress. Swelling of thylakoids and disruption of chloroplast envelopes in mesophyll cells along with intact chloroplasts in bundle sheath cells is a general $\mathrm{C}_{4}$ response under salinity, irrespective of the subtype.

Halophytes and glycophytes have evolved different pathways to respond to salinity stress. For example, halophytes are much better adapted at maintaining a lower salt concentration in the cytoplasm compared to glycophytes. Likewise, chloroplasts in halophytes seem to have a better antioxidant system than those of glycophytes, and consequently more protected photosynthetic apparatuses under salt stress. Similarly, salinity-triggered starch 
deposition appears to be a damage symptom in glycophytes but a survival strategy in halophytes. The salinity-induced influx of $\mathrm{Na}^{+}$and $\mathrm{Cl}^{-}$appears beneficial for halophytes but lethal for glycophytes (Figure 1). Accumulation of $\mathrm{Na}^{+} \mathrm{or} \mathrm{Cl}^{-}$disrupts ionic homeostasis, impairs protein synthesis and interferes with the enzymatic activities of the organelle. However, recent work suggests that the negative effects of these ions on plant health are not because of toxicity per se but are the result of interference with the absorption or metabolism of other essential ions [28]. This view stems from the evidence that $\mathrm{K}^{+}$influx in chloroplasts is reduced with excessive $\mathrm{Na}^{+}$or $\mathrm{Cl}^{-}$accumulation. $\mathrm{K}^{+}$is an essential element for the plant cell and is not only required for chloroplast development but also for $\mathrm{pH}$ regulation, maintenance of the electron transport chain and thylakoid restacking [28,29]. Osmolyte synthesis suggests that organic solutes may help in fine adjustment along with ion transport (vacuolar compartmentation) and accumulation of cytosolic $\mathrm{K}^{+}$in stressed environments rather than osmotic adjustment. However, osmolytes are certainly involved in the osmoprotection of membrane transport proteins and the scavenging of ROS. Despite ion regulation and osmotic adjustment, salinity induces many changes in chloroplast functions and signaling.

Chloroplastic $\mathrm{CO}_{2}$ fixation is generally more sensitive to salinity than the thylakoid reactions. However, $\mathrm{CO}_{2}$ fixation in many halophytes is reportedly less prone to salinity compared to glycophytes. One major evolutionary adaptation that seems to operate in halophytes is the switching of $\mathrm{CO}_{2}$ concentration around Rubisco under stressful environmental conditions, including salinity. The reduced photosynthetic efficiency is considered a major salt-induced constraint inhibiting plant growth, and ultimately crop productivity. However, it is not yet clear whether the decrease in photosynthesis is the cause of growth reduction or the reduction in the growth rate causes a decrease in photosynthesis under salt stress. Nevertheless, a reduced rate of photosynthesis leads to higher production of ROS and also triggers the activity of ROS-scavenging enzymes. The higher activity of the ROS-detoxifying enzymes maintains a level of these species in a functionally useful range required for cell signaling. These enzymatic systems are naturally present in plants. Although differences in the activity of these enzymes have been reported in different genotypes, it is believed to be associated with responses such as stomatal closures, reduction in the $\mathrm{CO}_{2}$ fixation rates and an increase in photorespiration under stressful conditions [188,194]. Tight regulation of ROS alongside many chloroplastic metabolites also function as 'putative' signals for communication between chloroplasts and the nucleus (as well as other organelles) via so-called 'retrograde signaling'. Despite information on crop and model plants, our knowledge about such signaling in halophytes is still far from full comprehension. Chloroplast functions, including photosynthesis, are integrated with other basic plant metabolic mechanisms of the plant in response to stresses, including salinity, and multiple factors work together to confer tolerance against salinity [195]. These factors include ion regulation that controls uptake and transport of salt and other ions to compartments within the plant cell, synthesis of compatible solutes, antioxidative enzymes and plant hormones and changes in photosynthesis and membranes in the cell [195]. Some of these occur within the chloroplast but are not limited to that location. These mechanisms are quite complicated, and many questions remain unanswered [195,196]. Some of these questions include how the plant senses salinity to initiate the signaling process, the precise details of how salinity stress leads to stomatal closure and growth reduction and the specific targets of ion toxicity in plant cells [196]. While advances are being made, a detailed understanding of the mechanisms behind salt tolerance is not yet clear. A comprehensive understanding of these mechanisms by employing multidisciplinary approaches is necessary for their effective incorporation into salt-sensitive crops for better crop yields under stressful environments.

Author Contributions: All authors participated in the writing of different sections, editing, and proofreading of the manuscript; M.Z.A. (Figure 1) and A.H. (Figure 2) prepared the figures. All authors have read and agreed to the published version of the manuscript. 
Funding: No specific funding was received for this work.

Institutional Review Board Statement: Not applicable.

Informed Consent Statement: Not applicable.

Data Availability Statement: As a review paper all data is available in the work referenced.

Acknowledgments: We are grateful to Narendra K. Singh, Auburn University (emeritus), for helpful discussions in developing this review.

Conflicts of Interest: The authors declare no conflict of interest.

\section{References}

1. Hussain, T.M.; Chandrasekhar, T.; Hazara, J.; Sultan, Z.; Saleh, B.K.; Gopal, G.R. Recent advances in salt stress biology-A review. Biotech. Mol. Biol. Rev. 2008, 3, 8-13.

2. Allakhverdiev, S.I.; Murata, N. Salt stress inhibits photosystems II and I in cyanobacteria. Photosynth. Res. 2008, 98, 529-539. [CrossRef]

3. Akyol, T.Y.; Yilmaz, O.; Uzİlday, B.; Uzİlday, R.Ö.; Türkan, İ. Plant response to salinity: An analysis of ROS formation, signaling, and antioxidant defense. Turk. J. Bot. 2020, 44, 1-13. [CrossRef]

4. $\quad$ Badawi, G.H.; Yamauchi, E.Y.; Shimada, R.; Sasaki, N.; Kawano, K.; Tanaka, K.; Tanaka, K. Enhanced tolerance to salt stress and water deficit by overexpressing superoxide dismutase in tobacco (Nicotiana tabacum) chloroplasts. Plant Sci. 2004, 166, 919-928. [CrossRef]

5. Jing, X.; Hou, P.; Lu, Y.; Deng, S.; Li, N.; Zhao, R.; Sun, J.; Wang, Y.; Han, Y.; Lang, T. Overexpression of copper/zinc superoxide dismutase from mangrove Kandelia candel in tobacco enhances salinity tolerance by the reduction of reactive oxygen species in chloroplast. Front. Plant Sci. 2015, 5, 23. [CrossRef]

6. Tseng, M.J.; Liu, C.-W.; Yiu, J.-C. Enhanced tolerance to sulfur dioxide and salt stress of transgenic Chinese cabbage plants expressing both superoxide dismutase and catalase in chloroplasts. Plant Physiol. Biochem. 2007, 45, 822-833. [CrossRef] [PubMed]

7. Koussevitzky, S.; Nott, A.; Mockler, T.C.; Hong, F.; Sachetto-Martins, G.; Surpin, M.; Lim, J.; Mittler, R.; Chory, J. Signals from chloroplasts converge to regulate nuclear gene expression. Science 2007, 316, 715-719. [CrossRef]

8. Munns, R.; Tester, M. Mechanisms of salinity tolerance. Ann. Rev. Plant Biol. 2008, 59, 651-681. [CrossRef] [PubMed]

9. Yan, K.; Shao, H.; Shao, C.; Chen, P.; Zhao, S.; Brestic, M.; Chen, X. Physiological adaptive mechanisms of plants grown in saline soil and implications for sustainable saline agriculture in coastal zone. Acta Physiol. Plant 2013, 35, 2867-2878. [CrossRef]

10. Abdelhamid, M.T.; Sekara, A.; Pessarakli, M.; Alarcon, J.J.; Brestic, M.; El-Ramady, H.; Gad, N.; Mohamed, H.I.; Fares, W.M.; Heba, S.S.; et al. New approaches for improving salt stress tolerance in rice. In Rice Research for Quality Improvement: Genomics and Genetic Engineering; Roychoudhury, A., Ed.; Springer: Singapore, 2020. [CrossRef]

11. Hajihashemi, S.; Skalicky, M.; Brestic, M.; Pavla, V. Cross-talk between nitric oxide, hydrogen peroxide and calcium in salt-stressed Chenopodium quinoa Willd. At seed germination stage. Plant Physiol. Biochem. 2020, 154, 657-664. [CrossRef]

12. Miransari, M.; Smith, D. Sustainable wheat (Triticum aestivum L.) production in saline fields: A review. Crit. Rev. Biotechnol. 2019, 39, 999-1014. [CrossRef]

13. Rasel, M.; Tahjib-Ul-Arif, M.; Hossain, M.A.; Hassan, L.; Farzana, S.; Brestic, M. Screening of salt-tolerant rice landraces by seedling stage phenotyping and dissecting biochemical determinants of tolerance mechanism. J. Plant Growth Regul. 2020, 1-16. [CrossRef]

14. Ibrahimova, U.; Kumari, P.; Yadav, S.; Rastogi, A.; Antala, M.; Suleymanova, Z.; Ziveak, M.; Tahjib-Ul-Arif, M.; Hussain, S.; Abdelhamid, M.; et al. Progress in understanding salt stress response in plants using biotechnological tools. J. Biotechnol. 2021, 329, 180-191. [CrossRef] [PubMed]

15. Flowers, T.J.; Colmer, T.D. Salinity Tolerance in Halophytes. New Phytol. 2008, 179, 945-963. [CrossRef] [PubMed]

16. Asrar, H.; Hussain, T.; Hadi, S.M.S.; Gul, B.; Nielsen, B.L.; Khan, M.A. Salinity induced changes in light harvesting and carbon assimilating complexes of Desmostachya bipinnata (L.) Staph. Environ. Exp. Bot. 2017, 135, 86-95. [CrossRef]

17. Bellasio, C.; Quirk, J.; Beerling, D.J. Stomatal and non-stomatal limitations in savanna trees and C4 grasses grown at low, ambient and high atmospheric $\mathrm{CO}_{2}$. Plant Sci. 2018, 274, 181-192. [CrossRef]

18. Flexas, J.; Barbour, M.M.; Brendel, O.; Cabrera, H.M.; Carriquí, M.; Díaz-Espejo, A.; Douthe, C.; Dreyer, E.; Ferrio, J.P.; Gago, J.; et al. Mesophyll diffusion conductance to $\mathrm{CO}_{2}$ : An unappreciated central player in photosynthesis. Plant Sci. 2012, 193-194, 70-84. [CrossRef]

19. Galmés, J.; Molins, A.; Flexas, J.; Conesa, M.À. Coordination between leaf $\mathrm{CO}_{2}$ diffusion and Rubisco properties allows maximizing photosynthetic efficiency in Limonium species. Plant Cell Environ. 2017, 40, 2081-2094. [CrossRef]

20. Hussain, T.; Huchzermeyer, B.; Koyro, H.-W.; Khan, M.A. Linkage between leaf development and photosynthetic response at hyperosmotic salinity in the C-4 grass Panicum antidotale. Flora 2019, 256, 52-60. [CrossRef]

21. Nunes-Nesi, A.; Nascimento, V.d.L.; de Oliveira Silva, F.M.; Zsögön, A.; Araújo, W.L.; Sulpice, R. Natural genetic variation for morphological and molecular determinants of plant growth and yield. J. Exp. Bot. 2016, 67, 2989-3001. [CrossRef] 
22. Rasouli, F.; Kiani-Pouya, A.; Tahir, A.; Shabala, L.; Chen, Z.; Shabala, S. A comparative analysis of stomatal traits and photosynthetic responses in closely related halophytic and glycophytic species under saline conditions. Environ. Exp. Bot. 2021, 181, 104300. [CrossRef]

23. Rastogi, A.; Kovar, M.; He, X.; Zivcak, M.; Kataria, S.; Kalaji, H.M.; Skalicky, M.; Ibrahimova, U.F.; Hussain, S.; Mbarki, S.; et al. JIP-test as a tool to identify salinity toelrance in sweet sorghum genotypes. Phostosynthetica 2020, 58, 518-520. [CrossRef]

24. Zuo, Z.; Ye, F.; Wang, Z.; Li, S.; Li, H.; Guo, J.; Mao, H.; Zhu, X.; Li, X. Salt acclimation induced salt tolerance in wild-type and chlrophyll b-deficient mutant wheat. Plant Soil Environ. 2021, 67, 26-32. [CrossRef]

25. Tomeo, N.J.; Rosenthal, D.M. Variable mesophyll conductance among soybean cultivars sets a tradeoff between photosynthesis and water-use-efficiency. Plant Physiol. 2017, 174, 241-257. [CrossRef] [PubMed]

26. Munns, R.; Passioura, J.B.; Colmer, T.D.; Byrt, C.S. Osmotic adjustment and energy limitations to plant growth in saline soil. New Phytol. 2020, 225, 1091-1096. [CrossRef] [PubMed]

27. Rodrigues, N.F.; da Fonseca, G.C.; Kulcheski, F.R.; Margis, R. Salt stress affects mRNA editing in soybean chloroplasts. Genet. Mol. Biol. 2017, 40, 200-208. [CrossRef] [PubMed]

28. Zhao, C.; Zhang, H.; Song, C.; Zhu, J.-K.; Shabala, S. Mechanisms of plant responses and adaptation to soil salinity. Innovation 2020, 1, 100017. [CrossRef]

29. Bose, J.; Munns, R.; Shabala, S.; Gilliham, M.; Pogson, B.; Tyerman, S.D. Chloroplast function and ion regulation in plants growing on saline soils: Lessons from halophytes. J. Exp. Bot. 2017, 68, 3129-3143. [CrossRef]

30. Pan, T.; Liu, M.; Kreslavski, V.D.; Zharmukhamedov, S.K.; Nie, C.; Yu, M.; Kuznetsov, V.V.; Allakhverdiev, S.I.; Shabala, S. Non-stomatal limitation of photosynthesis by soil salinity. Crit. Rev. Environ. Sci. Technol. 2021, 51, 791-825. [CrossRef]

31. Gulzar, S.; Hussain, T.; Gul, B.; Hameed, A. Photosynthetic Adaptations and Oxidative Stress Tolerance in Halophytes from Warm Subtropical Region; Springer: Cham, Switzerland, 2020. [CrossRef]

32. Maxwell, K.; Johnson, G.N. Chlorophyll fluorescence-A practical guide. J. Exp. Bot. 2000, 51, 659-668. [CrossRef]

33. Ashraf, M.; Harris, P.J.C. Photosynthesis under stressful environments: An overview. Photosynthetica 2013, 51, 163-190. [CrossRef]

34. Koyro, H.-W.; Hussain, T.; Huchzermeyer, B.; Khan, M.A. Photosynthetic and growth responses of a perennial halophytic grass Panicum turgidum to increasing $\mathrm{NaCl}$ concentrations. Environ. Exp. Bot. 2013, 91, 22-29. [CrossRef]

35. Loreto, F.; Centritto, M.; Chartzoulakis, K. Photosynthetic limitations in olive cultivars with different sensitivity to salt stress. Plant Cell Environ. 2003, 26, 595-601. [CrossRef]

36. Cooper, G.M. The Cell: A Molecular Approach, 2nd ed.; Sinauer Associates: Sunderland, MA, USA, 2000.

37. Papadakis, I.E.; Giannakoula, A.; Therios, I.N.; Bosabalidis, A.M.; Moustakas, M.; Nastou, A. Mn-induced changes in leaf structure and chloroplast ultrastructure of Citrus volkameriana (L.) plants. J. Plant Physiol. 2007, 164, 100-103. [CrossRef]

38. Blumenthal-Goldschmidt, S.; Poljakoff-Mayber, A. Effect of substrate salinity on growth and submicroscopic structure of leaf cells of A. halimus L. Aust. J. Bot. 1968, 16, 469-478. [CrossRef]

39. Hall, J.; Barr, R.; Al-Abbas, A.; Crane, F. The ultrastructure of chloroplasts in mineral-deficient maize leaves. Plant Physiol. 1972, 50, 404-409. [CrossRef]

40. Kelley, D.B. Salinity Effects on Growth and Fine Structure of Atriplex halimus L. Master's Thesis, Texas Tech University, Lubbock, TX, USA, 1974. Available online: http:/ /hdl.handle.net/2346/20673 (accessed on 3 August 2021).

41. Štefanić, P.P.; Koffler, T.; Adler, G.; Bar-Zvi, D. Chloroplasts of salt-grown Arabidopsis seedlings are impaired in structure, genome copy number and transcript levels. PLoS ONE 2013, 8, e82548. [CrossRef]

42. Salama, S.; Trivedi, S.; Busheva, M.; Arafa, A.; Garab, G.; Erdei, L. Effects of NaCl salinity on growth, cation accumulation, chloroplast structure and function in wheat cultivars differing in salt tolerance. J. Plant Physiol. 1994, 144, 241-247. [CrossRef]

43. Preiss, J. Starch, sucrose biosynthesis and partition of carbon in plants are regulated by orthophosphate and triose-phosphates. Trends Biochem. Sci. 1984, 9, 24-27. [CrossRef]

44. Szabo-Nagy, A.; Galiba, G.; Erdei, L. Induction of soluble phosphatases under ionic and non-ionic osmotic stresses in wheat. J. Plant Physiol. 1992, 140, 629-633. [CrossRef]

45. Shu, S.; Guo, S.R.; Sun, J.; Yuan, L.Y. Effects of salt stress on the structure and function of the photosynthetic apparatus in Cucumis sativus and its protection by exogenous putrescine. Physiol. Plant. 2012, 146, 285-296. [CrossRef] [PubMed]

46. Chang, L.; Guo, A.; Jin, X.; Yang, Q.; Wang, D.; Sun, Y.; Huang, Q.; Wang, L.; Peng, C.; Wang, X. The beta subunit of glyceraldehyde 3-phosphate dehydrogenase is an important factor for maintaining photosynthesis and plant development under salt stressBased on an integrative analysis of the structural, physiological and proteomic changes in chloroplasts in Thellungiella halophila. Plant Sci. 2015, 236, 223-238.

47. Delfine, S.; Alvino, A.; Zacchini, M.; Loreto, F. Consequences of salt stress on conductance to $\mathrm{CO}_{2}$ diffusion, Rubisco characteristics and anatomy of spinach leaves. Funct. Plant Biol. 1998, 25, 395-402. [CrossRef]

48. Mitsuya, S.; Takeoka, Y.; Miyake, H. Effects of sodium chloride on foliar ultrastructure of sweet potato (Ipomoea batatas Lam.) plantlets grown under light and dark conditions in vitro. J. Plant Physiol. 2000, 157, 661-667. [CrossRef]

49. Wang, L.; Liang, W.; Xing, J.; Tan, F.; Chen, Y.; Huang, L.; Cheng, C.L.; Chen, W. Dynamics of chloroplast proteome in salt-stressed mangrove Kandelia candel (L.) Druce. J. Proteome Res. 2013, 12, 5124-5136. [CrossRef]

50. Yamane, K.; Kawasaki, M.; Taniguchi, M.; Miyake, H. Correlation between chloroplast ultrastructure and chlorophyll fluorescence characteristics in the leaves of rice (Oryza sativa L.) grown under salinity. Plant Prod. Sci. 2008, 11, 139-145. [CrossRef] 
51. Oi, T.; Enomoto, S.; Nakao, T.; Arai, S.; Yamane, K.; Taniguchi, M. Three-dimensional ultrastructural change of chloroplasts in rice mesophyll cells responding to salt stress. Ann. Bot. 2020, 125, 833-840. [CrossRef]

52. Gao, H.-J.; Yang, H.-Y.; Bai, J.-P.; Liang, X.-Y.; Lou, Y.; Zhang, J.-L.; Wang, D.; Zhang, J.-L.; Niu, S.-Q.; Chen, Y. Ultrastructural and physiological responses of potato (Solanum tuberosum L.) plantlets to gradient saline stress. Front. Plant Sci. $2015,5,787$. [CrossRef]

53. Hasan, R.; Kawasaki, M.; Taniguchi, M.; Miyake, H. Salinity stress induces granal development in bundle sheath chloroplasts of maize, an NADP-malic enzyme-type C4 plant. Plant Prod. Sci. 2006, 9, 256-265. [CrossRef]

54. Goussi, R.; Manaa, A.; Derbali, W.; Cantamessa, S.; Abdelly, C.; Barbato, R. Comparative analysis of salt stress, duration and intensity, on the chloroplast ultrastructure and photosynthetic apparatus in Thellungiella salsuginea. J. Photochem. Photobiol. B Biol. 2018, 183, 275-287. [CrossRef] [PubMed]

55. Parida, A.K.; Das, A.B.; Mittra, B. Effects of nacl stress on the structure, pigment complex composition, and photosynthetic activity of mangrove Bruguiera parviflora chloroplasts. Photosynthet 2003, 41, 191. [CrossRef]

56. Yoshimura, Y.; Kubota, F.; Ueno, O. Structural and biochemical bases of photorespiration in C4 plants: Quantification of organelles and glycine decarboxylase. Planta 2004, 220, 307-317. [CrossRef]

57. Omoto, E.; Kawasaki, M.; Taniguchi, M.; Miyake, H. Salinity induces granal development in bundle sheath chloroplasts of NADP-malic enzyme type C4 plants. Plant Prod. Sci. 2009, 12, 199-207. [CrossRef]

58. Omoto, E.; Taniguchi, M.; Miyake, H. Effects of salinity stress on the structure of bundle sheath and mesophyll chloroplasts in NAD-malic enzyme and PCK type C4 plants. Plant Prod. Sci. 2010, 13, 169-176. [CrossRef]

59. Kubínová, Z.; Janáček, J.; Lhotáková, Z.; Kubínová, L.; Albrechtová, J. Unbiased estimation of chloroplast number in mesophyll cells: Advantage of a genuine three-dimensional approach. J. Exp. Bot. 2013, 65, 609-620. [CrossRef] [PubMed]

60. Winter, H.; Robinson, D.G.; Heldt, H.W. Subcellular volumes and metabolite concentrations in barley leaves. Planta 1993, 191, 180-190. [CrossRef]

61. Marschner, H.; Possingham, J.V. Effect of $\mathrm{K}^{+}$and $\mathrm{Na}^{+}$on growth of leaf discs of sugar beet and spinach. Z. Pflanzenphysiol. 1975, 75, 6-16. [CrossRef]

62. Aldesuquy, H.; Baka, Z.; Mickky, B. Kinetin and spermine mediated induction of salt tolerance in wheat plants: Leaf area, photosynthesis and chloroplast ultrastructure of flag leaf at ear emergence. Egypt. J. Basic Appl. Sci. 2014, 1, 77-87. [CrossRef]

63. Flowers, T.J.; Munns, R.; Colmer, T.D. Sodium chloride toxicity and the cellular basis of salt tolerance in halophytes. Ann. Bot. 2014, 115, 419-431. [CrossRef] [PubMed]

64. Cosentino, C.; Fischer-Schliebs, E.; Bertl, A.; Thiel, G.; Homann, U. Na ${ }^{+} / \mathrm{H}^{+}$antiporters are differentially regulated in response to $\mathrm{NaCl}$ stress in leaves and roots of Mesembryanthemum crystallinum. New Phytol. 2010, 186, 669-680. [CrossRef]

65. Robinson, S.; Downton, W. Potassium, sodium and chloride ion concentrations in leaves and isolated chloroplasts of the halophyte Suaeda australis R. Br. Aust. J. Plant Physiol. 1985, 12, 471-479. [CrossRef]

66. Robinson, S.P.; Downton, W.J.S. Potassium, sodium, and chloride content of isolated intact chloroplasts in relation to ionic compartmentation in leaves. Arch. Biochem. Biophys. 1984, 228, 197-206. [CrossRef]

67. Müller, M.; Kunz, H.-H.; Schroeder, J.I.; Kemp, G.; Young, H.S.; Neuhaus, H.E. Decreased capacity for sodium export out of Arabidopsis chloroplasts impairs salt tolerance, photosynthesis and plant performance. Plant J. 2014, 78, 646-658. [CrossRef] [PubMed]

68. Yoshida, Y.; Miyagishima, S.-y.; Kuroiwa, H.; Kuroiwa, T. The plastid-dividing machinery: Formation, constriction and fission. Curr. Opin. Plant Biol. 2012, 15, 714-721. [CrossRef] [PubMed]

69. Jarvis, P.; López-Juez, E. Biogenesis and homeostasis of chloroplasts and other plastids. Nat. Rev. Mol. Cell Biol. 2013, 14, 787-802. [CrossRef] [PubMed]

70. Osteryoung, K.W.; Pyke, K.A. Division and Dynamic Morphology of Plastids. Annu. Rev. Plant Biol. 2014, 65, 443-472. [CrossRef]

71. Soll, J. Protein import into chloroplasts. Curr. Opin. Plant Biol. 2002, 5, 529-535. [CrossRef]

72. Ling, Q.; Jarvis, P. Regulation of chloroplast protein import by the ubiquitin E3 ligase SP1 is important for stress tolerance in plants. Curr. Biol. 2015, 25, 2527-2534. [CrossRef] [PubMed]

73. Pottosin, I.; Dobrovinskaya, O. Ion channels in native chloroplast membranes: Challenges and potential for direct patch-clamp studies. Front. Physiol. 2015, 6, 396. [CrossRef]

74. Beebo, A.; Mathai, J.C.; Schoefs, B.; Spetea, C. Assessment of the requirement for aquaporins in the thylakoid membrane of plant chloroplasts to sustain photosynthetic water oxidation. FEBS Lett. 2013, 587, 2083-2089. [CrossRef]

75. Pottosin, I.; Shabala, S. Transport across chloroplast membranes: Optimizing photosynthesis for adverse environmental conditions. Mol. Plant 2016, 9, 356-370. [CrossRef]

76. Tanz, S.K.; Castleden, I.; Hooper, C.M.; Vacher, M.; Small, I.; Millar, H.A. SUBA3: A database for integrating experimentation and prediction to define the SUB cellular location of proteins in Arabidopsis. Nucl. Acids Res. 2012, 41, D1185-D1191. [CrossRef]

77. Hooper, C.M.; Tanz, S.K.; Castleden, I.R.; Vacher, M.A.; Small, I.D.; Millar, A.H. SUBAcon: A consensus algorithm for unifying the subcellular localization data of the Arabidopsis proteome. Bioinformatics 2014, 30, 3356-3364. [CrossRef]

78. Finazzi, G.; Petroutsos, D.; Tomizioli, M.; Flori, S.; Sautron, E.; Villanova, V.; Rolland, N.; Seigneurin-Berny, D. Ions channels/transporters and chloroplast regulation. Cell Calcium 2015, 58, 86-97. [CrossRef] [PubMed]

79. Slabu, C.; Zörb, C.; Steffens, D.; Schubert, S. Is salt stress of faba bean (Vicia faba) caused by $\mathrm{Na}^{+}$or $\mathrm{Cl}^{-}$toxicity? J. Plant Nutr. Soil Sci. 2009, 172, 644-651. [CrossRef] 
80. Chen, X.-Q.; Yu, B.-J. Ionic effects of $\mathrm{Na}^{+}$and $\mathrm{Cl}^{-}$on photosynthesis in Glycine max seedlings under isoosmotic salt stress. J. Plant Physiol. Mol. Biol. 2007, 33, 294-300.

81. Subbarao, G.; Ito, O.; Berry, W.; Wheeler, R. Sodium-A functional plant nutrient. Crit. Rev. Plant Sci. 2003, 22, 391-416. [CrossRef]

82. Furumoto, T.; Yamaguchi, T.; Ohshima-Ichie, Y.; Nakamura, M.; Tsuchida-Iwata, Y.; Shimamura, M.; Ohnishi, J.; Hata, S.; Gowik, U.; Westhoff, P. A plastidial sodium-dependent pyruvate transporter. Nature 2011, 476, 472-475. [CrossRef]

83. Zhao, Y.; Ai, X.; Wang, M.; Xiao, L.; Xia, G. A putative pyruvate transporter TaBASS2 positively regulates salinity tolerance in wheat via modulation of ABI4 expression. BMC Plant Biol. 2016, 16, 1-12. [CrossRef]

84. Miyaji, T.; Kuromori, T.; Takeuchi, Y.; Yamaji, N.; Yokosho, K.; Shimazawa, A.; Sugimoto, E.; Omote, H.; Ma, J.F.; Shinozaki, K. AtPHT4;4 is a chloroplast-localized ascorbate transporter in Arabidopsis. Nat. Commun. 2015, 6, 1-11. [CrossRef]

85. Guo, B.; Irigoyen, S.; Fowler, T.B.; Versaw, W.K. Differential expression and phylogenetic analysis suggest specialization of plastid-localized members of the PHT4 phosphate transporter family for photosynthetic and heterotrophic tissues. Plant Signal. Behav. 2008, 3, 784-790. [CrossRef]

86. Percey, W.J.; McMinn, A.; Bose, J.; Breadmore, M.C.; Guijt, R.M.; Shabala, S. Salinity effects on chloroplast PSII performance in glycophytes and halophytes. Funct. Plant Biol. 2016, 43, 1003-1015. [CrossRef]

87. Pou, A.; Jeanguenin, L.; Milhiet, T.; Batoko, H.; Chaumont, F.; Hachez, C. Salinity-mediated transcriptional and post-translational regulation of the Arabidopsis aquaporin PIP2;7. Plant Mol. Biol. 2016, 92, 731-744. [CrossRef]

88. Byrt, C.S.; Zhao, M.; Kourghi, M.; Bose, J.; Henderson, S.W.; Qiu, J.; Gilliham, M.; Schultz, C.; Schwarz, M.; Ramesh, S.A. Non-selective cation channel activity of aquaporin AtPIP2; 1 regulated by $\mathrm{Ca}^{2+}$ and pH. Plant Cell Environ. 2017, 40, 802-815. [CrossRef]

89. Wilson, M.E.; Basu, M.R.; Bhaskara, G.B.; Verslues, P.E.; Haswell, E.S. Plastid osmotic stress activates cellular stress responses in Arabidopsis. Plant Physiol. 2014, 165, 119-128. [CrossRef] [PubMed]

90. Ottow, E.A.; Polle, A.; Brosche, M.; Kangasjärvi, J.; Dibrov, P.; Zörb, C.; Teichmann, T. Molecular characterization of PeNhaD1: The first member of the $\mathrm{NhaD} \mathrm{Na}{ }^{+} / \mathrm{H}^{+}$antiporter family of plant origin. Plant Mol. Biol. 2005, 58, 75-88. [CrossRef] [PubMed]

91. Kunz, H.-H.; Gierth, M.; Herdean, A.; Satoh-Cruz, M.; Kramer, D.M.; Spetea, C.; Schroeder, J.I. Plastidial transporters KEA1, -2, and -3 are essential for chloroplast osmoregulation, integrity, and $\mathrm{pH}$ regulation in Arabidopsis. Proc. Natl. Acad. Sci. USA 2014, 111, 7480-7485. [CrossRef] [PubMed]

92. Armbruster, U.; Carrillo, L.R.; Venema, K.; Pavlovic, L.; Schmidtmann, E.; Kornfeld, A.; Jahns, P.; Berry, J.A.; Kramer, D.M.; Jonikas, M.C. Ion antiport accelerates photosynthetic acclimation in fluctuating light environments. Nat. Commun. 2014, 5, 1-8. [CrossRef] [PubMed]

93. Herdean, A.; Teardo, E.; Nilsson, A.K.; Pfeil, B.E.; Johansson, O.N.; Ünnep, R.; Nagy, G.; Zsiros, O.; Dana, S.; Solymosi, K. A voltage-dependent chloride channel fine-tunes photosynthesis in plants. Nat. Commun. 2016, 7, 11654. [CrossRef] [PubMed]

94. Munns, R. Why measure osmotic adjustment? Austral. J. Plant Physiol. 1988, 15, 717-726. [CrossRef]

95. Shabala, S.; Shabala, L. Ion transport and osmotic adjustment in plants and bacteria. BioMol. Concepts 2011, 2, 407-419. [CrossRef]

96. Chen, T.H.; Murata, N. Enhancement of tolerance of abiotic stress by metabolic engineering of betaines and other compatible solutes. Curr. Opin. Plant Biol. 2002, 5, 250-257. [CrossRef]

97. Delauney, A.J.; Verma, D.P.S. Proline biosynthesis and osmoregulation in plants. Plant J. 1993, 4, 215-223. [CrossRef]

98. Rivero, R.M.; Shulaev, V.; Blumwald, E. Cytokinin-dependent photorespiration and the protection of photosynthesis during water deficit. Plant Physiol. 2009, 150, 1530-1540. [CrossRef]

99. Shen, B.; Jensen, R.G.; Bohnert, H.J. Increased resistance to oxidative stress in transgenic plants by targeting mannitol biosynthesis to chloroplasts. Plant Physiol. 1997, 113, 1177-1183. [CrossRef] [PubMed]

100. Shen, B.; Jensen, R.G.; Bohnert, H.J. Mannitol protects against oxidation by hydroxyl radicals. Plant Physiol. 1997, 115, 527-532. [CrossRef] [PubMed]

101. Liang, C.; Zhang, X.Y.; Luo, Y.; Wang, G.P.; Zou, Q.; Wang, W. Overaccumulation of glycine betaine alleviates the negative effects of salt stress in wheat. Russ. J. Plant Physiol. 2009, 56, 370-376. [CrossRef]

102. Tian, F.; Wang, W.; Lianga, W.C.; Wanga, X.; Wanga, G.; Wanga, W. Overaccumulation of glycine betaine makes the function of the thylakoid membrane better in wheat under salt stress. Crop J. 2017, 5, 73-82. [CrossRef]

103. Park, E.J.; Jekni'c, Z.; Pino, M.T.; Murata, N.; Chen, T.H.H. Glycinebetaine accumulation is more effective in chloroplasts than in the cytosol for protecting transgenic tomato plants against abiotic stress. Plant Cell Environ. 2007, 30, 994-1005. [CrossRef]

104. Kurepin, L.V.; Ivanov, A.G.; Zaman, M.; Pharis, R.P.; Hurry, V.; Hüner, N.P. Interaction of glycine betaine and plant hormones: Protection of the photosynthetic apparatus during abiotic stress. In Photosynthesis: Structures, Mechanisms, and Applications; Hou, H.J.M., Najafpour, M.M., Moore, G.F., Allakhverdiev, S.I., Eds.; Springer: Berlin, Germany, 2017; pp. $185-202$.

105. Li, H.W.; Zang, B.S.; Deng, X.W.; Wang, X.P. Overexpression of the trehalose-6-phosphate synthase gene OsTPS1 enhances abiotic stress tolerance in rice. Planta 2011, 234, 1007-1018. [CrossRef]

106. Kanayama, Y.; Watanabe, M.; Moriguchi, R.; Deguchi, M.; Kanahama, K.; Yamaki, S. Effects of Low Temperature and Abscisic Acid on the Expression of the Sorbitol-6-phosphate Dehydrogenase Gene in Apple Leaves. J. Jpn. Soc. Hortic. Sci. 2006, 75, 20-25. [CrossRef]

107. Sleator, R.D.; Hill, C. Bacterial osmoadaptation: The role of osmolytes in bacterial stress and virulence. FEMS Microbiol. Rev. 2002, 26, 49-71. [CrossRef] [PubMed] 
108. Kunte, H.J. Osmoregulation in bacteria: Compatible solute accumulation and osmosensing. Environ. Chem. $2006,3,94-99$. [CrossRef]

109. Colmer, T.D.; Flowers, T.J.; Munns, R. Use of wild relatives to improve salt tolerance in wheat. J. Exp. Bot. 2006, 57, 1059-1078. [CrossRef] [PubMed]

110. Ruffino, A.M.C.; Rosa, M.; Hilal, M.; Gonzalez, J.A.; Prado, F.E. The role of cotyledon metabolism in the establishment of quinoa (Chenopodium quinoa) seedlings growing under salinity. Plant Soil. 2010, 326, 213-224. [CrossRef]

111. Kohl, K.I. The effect of $\mathrm{NaCl}$ on growth, dry matter allocation and ion uptake in salt marsh and inland populations of Armeria maritima. New Phytol. 1997, 135, 213-225. [CrossRef]

112. Khan, M.A.; Ungar, I.A.; Showalter, A.M.; Dewald, H.D. NaCl-induced accumulation of glycinebetaine in four subtropical halophytes from Pakistan. Physiol. Plant. 1998, 102, 487-492. [CrossRef]

113. Oren, A. Bioenergetic aspects of halophilism. Microbiol. Mol. Biol. Rev. 1999, 63, 334-348. [CrossRef] [PubMed]

114. Raven, J.A. Regulation of $\mathrm{pH}$ and generation of osmolarity in vascular plants: A cost-benefit analysis in relation to efficiency of use of energy, nitrogen and water. New Phytol. 1985, 101, 25-77. [CrossRef]

115. Lutts, S.; Majerus, V.; Kinet, J.M. NaCl effects on proline metabolism in rice (Oryza sativa) seedlings. Physiol. Plant. 1999, 105, 450-458. [CrossRef]

116. Bonner, C.A.; Williams, D.S.; Aldrich, H.C.; Jensen, R.A. Antagonism by L-glutamine of toxicity and growth inhibition caused by other amino acids in suspension cultures of Nicotiana silvestris. Plant Sci. 1996, 113, 43-58. [CrossRef]

117. Hare, P.D.; Cress, W.A.; van Staden, J. Disruptive effects of exogenous proline on chloroplast and mitochondrial ultrastructure in Arabidopsis leaves. S. Afr. J. Bot. 2002, 68, 393-396. [CrossRef]

118. Borgo, L.; Marur, C.J.; Vieira, L.G.E. Effects of high proline accumulation on chloroplast and mitochondrial ultrastructure and on osmotic adjustment in tobacco plants. Acta Sci. 2015, 37, 191-199. [CrossRef]

119. Chatterjee, J.; Patra, B.; Mukherjee, R.; Basak, P.; Mukherjee, S.; Ray, S.; Bhattacharyya, S.; Maitra, S.; Ghosh Dastidar, K.; Ghosh, S. Cloning, characterization and expression of a chloroplastic fructose-1,6-bisphosphatase from Porteresia coarctata conferring salt-tolerance in transgenic tobacco. Plant Cell Tissue Organ Cult. 2013, 114, 395-409. [CrossRef]

120. Cuin, T.A.; Shabal, A.S. Exogenously supplied compatible solutes rapidly ameliorate NaCl-induced potassium efflux from barley roots. Plant Cell Physiol. 2005, 46, 1924-1933. [CrossRef]

121. Leigh, R.A. Potassium homeostasis and membrane transport. J. Plant Nutr. Soil Sci. Pflanz. Bodenkd 2001, 164, 193-198. [CrossRef]

122. Glenn, E.P.; Brown, J.J.; Blumwald, E. Salt tolerance and crop potential of halophytes. Crit. Rev. Plant Sci. 1999, 18, 227-255. [CrossRef]

123. Tiwari, B.S.; Bose, A.; Ghosh, B. Photosynthesis in rice under a salt stress. Photosynthetica 1998, 34, 303-306. [CrossRef]

124. Belkhodja, R.; Morales, F.; Abadía, A.; Medrano, H.; Abadía, J. Effects of salinity on chlorophyll fluorescence and photosynthesis of barley (Hordeum vulgare L.) grown under a triple-line-source sprinkler system in the field. Photosynthetica 1999, 36, 375-387. [CrossRef]

125. Faseela, P.; Sinisha, A.K.; Brestic, M.; Puthur, J.T. Chlorophyll a fluorescence parameters as indicators of a particular abiotic stress in rice. Photosynthetica 2020, 58, 293-300. [CrossRef]

126. Allakhverdiev, S.I.; Nishiyama, Y.; Miyairi, S.; Yamamoto, H.; Inagaki, N.; Kanesaki, Y.; Murata, N. Salt stress inhibits the repair of photodamaged photosystem II by suppressing the transcription and translation of psbAGenes in synechocystis. Plant Physiol. 2002, 130, 1443-1453. [CrossRef]

127. Takahashi, S.; Murata, N. How do environmental stresses accelerate photoinhibition? Trends Plant Sci. 2008, 13, 178-182. [CrossRef]

128. Sengupta, S.; Majumder, A.L. Insight into the salt tolerance factors of a wild halophytic rice, Porteresia coarctata: A physiological and proteomic approach. Planta 2009, 229, 911-929. [CrossRef]

129. Rahman, S.; Matsumuro, T.; Miyake, H.; Takeoka, Y. Salinity-induced ultrastructural alterations in leaf cells of rice (Oryza sativa L.). Plant Prod. Sci. 2000, 3, 422-429. [CrossRef]

130. Redondo-Gómez, S.; Mateos-Naranjo, E.; Figueroa, M.E.; Davy, A.J. Salt stimulation of growth and photosynthesis in an extreme halophyte, Arthrocnemum macrostachyum. Plant Biol. 2010, 12, 79-87. [CrossRef] [PubMed]

131. Trotta, A.; Redondo-Gómez, S.; Pagliano, C.; Clemente, M.E.F.; Rascio, N.; La Rocca, N.; Antonacci, A.; Andreucci, F.; Barbato, R. Chloroplast ultrastructure and thylakoid polypeptide composition are affected by different salt concentrations in the halophytic plant Arthrocnemum macrostachyum. J. Plant Physiol. 2012, 169, 111-116. [CrossRef]

132. Redondo-Gómez, S.; Wharmby, C.; Castillo, J.M.; Mateos-Naranjo, E.; Luque, C.J.; De Cires, A.; Luque, T.; Davy, A.J.; Enrique Figueroa, M. Growth and photosynthetic responses to salinity in an extreme halophyte, Sarcocornia fruticosa. Physiol. Plant. 2006, 128, 116-124. [CrossRef]

133. Qiu, N.; Lu, Q.; Lu, C. Photosynthesis, photosystem II efficiency and the xanthophyll cycle in the salt-adapted halophyte Atriplex centralasiatica. New Phytol. 2003, 159, 479-486. [CrossRef] [PubMed]

134. Niyogi, K.K. Photoprotection revisited: Genetic and molecular approaches. Annu. Rev. Plant Physiol. Plant Mol. Biol. 1999, 50, 333-359. [CrossRef] [PubMed]

135. Munekage, Y.; Hashimoto, M.; Miyake, C.; Tomizawa, K.-I.; Endo, T.; Tasaka, M.; Shikanai, T. Cyclic electron flow around photosystem I is essential for photosynthesis. Nature 2004, 429, 579-582. [CrossRef] 
136. Johnson, G.N. Physiology of PSI cyclic electron transport in higher plants. Biochim. Biophys. Acta (BBA) Bioenerg. 2011, 1807, 384-389. [CrossRef] [PubMed]

137. Niewiadomska, E.; Wiciarz, M. Adaptations of chloroplastic metabolism in halophytic plants. In Progress in Botany; Springer: Berlin/Heidelberg, Germany, 2015; pp. 177-193.

138. Niewiadomska, E.; Bilger, W.; Gruca, M.; Mulisch, M.; Miszalski, Z.; Krupinska, K. CAM-related changes in chloroplastic metabolism of Mesembryanthemum crystallinum L. Planta 2011, 233, 275-285. [CrossRef] [PubMed]

139. He, Y.; Fu, J.; Yu, C.; Wang, X.; Jiang, Q.; Hong, J.; Lu, K.; Xue, G.; Yan, C.; James, A.; et al. Increasing cyclic electron flow is related to $\mathrm{Na}^{+}$sequestration into vacuoles for salt tolerance in soybean. J. Exp. Bot. 2015, 66, 6877-6889. [CrossRef] [PubMed]

140. Locy, R.D.; Chang, C.C.; Nielsen, B.L.; Singh, N.K. Photosynthesis in salt-adapted heterotrophic tobacco cells and regenerated plants. Plant Physiol. 1996, 110, 321-328. [CrossRef] [PubMed]

141. Chang, C.C.; Locy, R.D.; Smeda, R.; Sahi, S.V.; Singh, N.K. Photoautotrophic tobacco cells adapted to grow at high salinity. Plant Cell Rep. 1997, 16, 495-502. [CrossRef]

142. Ghosh, S.; Bagchi, S.; Lahiri Majumder, A. Chloroplast fructose-1,6-bisphosphatase from Oryza differs in salt tolerance property from the Porteresia enzyme and is protected by osmolytes. Plant Sci. 2001, 160, 1171-1181. [CrossRef]

143. Li, W.; Zhang, C.; Lu, Q.; Wen, X.; Lu, C. The combined effect of salt stress and heat shock on proteome profiling in Suaeda salsa. J. Plant Physiol. 2011, 168, 1743-1752. [CrossRef]

144. Taiz, L.; Zeiger, E.; Møller, I.M.; Murphy, A. Plant Physiology and Development; Sinauer Associates Incorporated: Sunderland, MA, USA, 2015.

145. Feller, U.; Anders, I.; Mae, T. Rubiscolytics: Fate of Rubisco after its enzymatic function in a cell is terminated. J. Exp. Bot. 2007, 59, 1615-1624. [CrossRef] [PubMed]

146. Sharpe, R.M.; Offermann, S. One decade after the discovery of single-cell C4 species in terrestrial plants: What did we learn about the minimal requirements of C4 photosynthesis? Photosynth. Res. 2014, 119, 169-180. [CrossRef]

147. Ziska, L.H.; Seemann, J.R.; DeJong, T.M. Salinity Induced Limitations on Photosynthesis in Prunus salicina, a Deciduous Tree Species 1. Plant Physiol. 1990, 93, 864-870. [CrossRef]

148. El-Shihaby, O.A.; Younis, M.E.; El-Bastawisy, Z.M.; Nemat Alla, M.M. Effect of kinetin on photosynthetic activity and carbohydrate content in waterlogged or seawater-treated Vigna sinensis and Zea mays plants. Plant Biosyst. Int. J. Deal. All Asp. Plant Biol. 2002, 136, 277-290. [CrossRef]

149. Osmond, C.B.; Greenway, H. Salt responses of carboxylation enzymes from species differing in salt tolerance. Plant Physiol. 1972, 49, 260-263. [CrossRef] [PubMed]

150. Gong, D.H.; Wang, G.Z.; Si, W.T.; Zhou, Y.; Liu, Z.; Jia, J. Effects of Salt Stress on Photosynthetic Pigments and Activity of Ribulose-1,5-bisphosphate Carboxylase/Oxygenase in Kalidium foliatum. Russ. J. Plant Physiol. 2018, 65, 98-103. [CrossRef]

151. Portis, A.R., Jr. Rubisco activase. Biochim. Biophys. Acta 1990, 1015, 15-28. [CrossRef]

152. Portis, A.R. Rubisco activase-Rubisco's catalytic chaperone. Photosynth. Res. 2003, 75, 11-27. [CrossRef]

153. Wiciarz, M.; Gubernator, B.; Kruk, J.; Niewiadomska, E. Enhanced chloroplastic generation of $\mathrm{H}_{2} \mathrm{O}_{2}$ in stress-resistant Thellungiella salsuginea in comparison to Arabidopsis thaliana. Physiol. Plant. 2015, 153, 467-476. [CrossRef]

154. Chueca, A.; Sahrawy, M.; Pagano, E.A.; López Gorgé, J. Chloroplast fructose-1,6-bisphosphatase: Structure and function. Photosynth. Res. 2002, 74, 235-249. [CrossRef]

155. Kanai, R.; Edwards, G.E. The biochemistry of C4 photosynthesis. C4 Plant Biol. 1999, $49,87$.

156. Yen, H.E.; Zhang, D.; Lin, J.-H.; Edwards, G.E.; Ku, M.S.B. Salt-induced changes in protein composition in light-grown callus of Mesembryanthemum crystallinum. Physiol. Plant. 1997, 101, 526-532. [CrossRef]

157. Leisner, C.P.; Cousins, A.B.; Offermann, S.; Okita, T.W.; Edwards, G.E. The effects of salinity on photosynthesis and growth of the single-cell C4 species Bienertia sinuspersici (Chenopodiaceae). Photosynth. Res. 2010, 106, 201-214. [CrossRef]

158. Parsley, K.; Hibberd, J.M. The Arabidopsis PPDK gene is transcribed from two promoters to produce differentially expressed transcripts responsible for cytosolic and plastidic proteins. Plant Mol. Biol. 2006, 62, 339-349. [CrossRef] [PubMed]

159. Burnell, J.N.; Chastain, C.J. Cloning and expression of maize-leaf pyruvate, Pi dikinase regulatory protein gene. Biochem. Biophys. Res. Commun. 2006, 345, 675-680. [CrossRef]

160. Chastain, C.J.; Heck, J.W.; Colquhoun, T.A.; Voge, D.G.; Gu, X.-Y. Posttranslational regulation of pyruvate, orthophosphate dikinase in developing rice (Oryza sativa) seeds. Planta 2006, 224, 924. [CrossRef]

161. Chastain, C.J.; Fries, J.P.; Vogel, J.A.; Randklev, C.L.; Vossen, A.P.; Dittmer, S.K.; Watkins, E.E.; Fiedler, L.J.; Wacker, S.A.; Meinhover, K.C.; et al. Pyruvate, orthophosphate dikinase in leaves and chloroplasts of C3 plants undergoes light-/dark-induced reversible phosphorylation. Plant Physiol. 2002, 128, 1368-1378. [CrossRef] [PubMed]

162. Ohta, S.; Ishida, Y.; Usami, S. Expression of cold-tolerant pyruvate, orthophosphate dikinase cDNA, and heterotetramer formation in transgenic maize plants. Transgenic Res. 2004, 13, 475-485. [CrossRef]

163. Omoto, E.; Taniguchi, M.; Miyake, H. Adaptation responses in C4 photosynthesis of maize under salinity. J. Plant Physiol. 2012, 169, 469-477. [CrossRef]

164. Chen, T.; Kahlen, K.; Stutzel, H. Disentangling the contributions of osmotic and ionic effects of salinity on stomatal, mesophyll, biochemical and light limitations to photosynthesis. Plant Cell Environ. 2015, 38, 1528-1542. [CrossRef] [PubMed]

165. Grassi, G.; Magnani, F. Stomatal, mesophyll conductance and biochemical limitations to photosynthesis as affected by drought and leaf ontogeny in ash and oak trees. Plant Cell Environ. 2005, 28, 834-849. [CrossRef] 
166. Tahjib-Ul-Arif, M.; Sohag, A.A.M.; Afrin, S.; Bashar, K.K.; Afrin, T.; Mahamud, S.U.; Polash, M.A.S.; Hossain, M.T.; Sohel, M.A.T.; Brestic, M.; et al. Differential response of sugar beet to long-term mild to severe salinity in a soil-pot culture. Agriculture 2019, 9, 223. [CrossRef]

167. Rabhi, M.; Castagna, A.; Remorini, D.; Scattino, C.; Smaoui, A.; Ranieri, A.; Abdelly, C. Photosynthetic responses to salinity in two obligate halophytes: Sesuvium portulacastrum and Tecticornia indica. S. Afr. J. Bot. 2012, 79, 39-47. [CrossRef]

168. Benzarti, M.; Ben Rejeb, K.; Debez, A.; Messedi, D.; Abdelly, C. Photosynthetic activity and leaf antioxidative responses of Atriplex portulacoides subjected to extreme salinity. Acta Physiol. Plant. 2012, 34, 1679-1688. [CrossRef]

169. Geissler, N.; Hussin, S.; Koyro, H.W. Elevated atmospheric $\mathrm{CO}_{2}$ concentration ameliorates effects of $\mathrm{NaCl}$ salinity on photosynthesis and leaf structure of Aster tripolium L. J. Exp. Bot. 2009, 60, 137-151. [CrossRef] [PubMed]

170. Duarte, B.; Santos, D.; Marques, J.C.; Caçador, I. Ecophysiological adaptations of two halophytes to salt stress: Photosynthesis, PS II photochemistry and anti-oxidant feedback-Implications for resilience in climate change. Plant Physiol. Biochem. 2013, 67, 178-188. [CrossRef]

171. Ben Hamed, K.; Dabbous, A.; Souid, A.; Abdelly, C. Antioxidant Molecules and Enzymes and Their Relevance to the Salt Adaptation of Halophytes. In Handbook of Halophytes; Grigore, M.N., Ed.; Springer: Cham, Switzerland, 2020. [CrossRef]

172. Ozgur, R.; Uzilday, B.; Sekmen, A.H.; Turkan, I. Reactive oxygen species regulation and antioxidant defence in halophytes. Funct. Plant Biol. 2013, 40, 832-847. [CrossRef]

173. Bose, J.; Rodrigo-Moreno, A.; Shabala, S. ROS homeostasis in halophytes in the context of salinity stress tolerance. J. Exp. Bot. 2013, 65, 1241-1257. [CrossRef] [PubMed]

174. Wrzaczek, M.; Brosché, M.; Kangasjärvi, J. ROS signaling loops-Production, perception, regulation. Curr. Opin. Plant Biol. 2013, 16, 575-582. [CrossRef]

175. Critchley, C. Stimulation of photosynthetic electron transport in a salt-tolerant plant by high chloride concentrations. Nature 1982, 298, 483-485. [CrossRef]

176. Stepien, P.; Johnson, G.N. Contrasting responses of photosynthesis to salt stress in the glycophyte Arabidopsis and the halophyte Thellungiella: Role of the plastid terminal oxidase as an alternative electron sink. Plant Physiol. 2008, 149, 1154-1165. [CrossRef] [PubMed]

177. Mittova, V.; Tal, M.; Volokita, M.; Guy, M. Salt stress induces up-regulation of an efficient chloroplast antioxidant system in the salt-tolerant wild tomato species Lycopersicon pennellii but not in the cultivated species. Physiol. Plant. 2002, 115, 393-400. [CrossRef] [PubMed]

178. Ahmad, N.; Michoux, F.; Nixon, P.J. Investigating the production of foreign membrane proteins in tobacco chloroplasts: Expression of an algal plastid terminal oxidase. PLoS ONE 2012, 7, e41722. [CrossRef]

179. Ahmad, N.; Khan, M.O.; Islam, E.; Wei, Z.-Y.; McAusland, L.; Lawson, T.; Johnson, G.N.; Nixon, P.J. Contrasting responses to stress displayed by tobacco overexpressing an algal plastid terminal oxidase in the chloroplast. Front. Plant Sci. 2020, 11, 501. [CrossRef]

180. Uzilday, B.; Ozgur, R.; Sekmen, A.H.; Yildiztugay, E.; Turkan, I. Changes in the alternative electron sinks and antioxidant defence in chloroplasts of the extreme halophyte Eutrema parvulum (Thellungiella parvula) under salinity. Ann. Bot. 2014, 115, 449-463. [CrossRef]

181. Jithesh, M.; Prashanth, S.; Sivaprakash, K.; Parida, A.K. Antioxidative response mechanisms in halophytes: Their role in stress defence. J. Genet. 2006, 85, 237. [CrossRef]

182. Shabala, S.; Bose, J.; Hedrich, R. Salt bladders: Do they matter? Trends Plant Sci. 2014, 19, 687-691. [CrossRef]

183. Shabala, S.; Wu, H.; Bose, J. Salt stress sensing and early signalling events in plant roots: Current knowledge and hypothesis. Plant Sci. 2015, 241, 109-119. [CrossRef] [PubMed]

184. Chan, K.X.; Phua, S.Y.; Crisp, P.; McQuinn, R.; Pogson, B.J. Learning the languages of the chloroplast: Retrograde signaling and beyond. Annu. Rev. Plant Biol. 2016, 67, 25-53. [CrossRef] [PubMed]

185. Mittler, R. Oxidative stress, antioxidants and stress tolerance. Trends Plant Sci. 2002, 7, 405-410. [CrossRef]

186. Sharma, P.; Jha, A.B.; Dubey, R.S.; Pessarakli, M. Reactive oxygen species, oxidative damage, and antioxidative defense mechanism in plants under stressful conditions. J. Bot. 2012, 2012, 217037. [CrossRef]

187. Suo, J.; Zhao, Q.; David, L.; Chen, S.; Dai, S. Salinity response in chloroplasts: Insights from gene characterization. Int. J. Mol. Sci. 2017, 18, 1011. [CrossRef] [PubMed]

188. Asada, K. Production and scavenging of reactive oxygen species in chloroplasts and their functions. Plant Physiol. 2006, 141, 391-396. [CrossRef]

189. Edreva, A. Generation and scavenging of reactive oxygen species in chloroplasts: A submolecular approach. Agric. Ecosyst. Environ. 2005, 106, 119-133. [CrossRef]

190. Noctor, G.; Foyer, C.H. Ascorbate and glutathione: Keeping active oxygen under control. Annu. Rev. Plant Physiol. Plant Mol. Biol. 1998, 49, 249-279. [CrossRef] [PubMed]

191. Miller, G.; Suzuki, N.; Ciftci-Yilmaz, S.; Mittler, R. Reactive oxygen species homeostasis and signalling during drought and salinity stresses. Plant Cell Environ. 2010, 33, 453-467. [CrossRef] [PubMed]

192. Triantaphylidès, C.; Havaux, M. Singlet oxygen in plants: Production, detoxification and signaling. Trends Plant Sci. 2009, 14, 219-228. [CrossRef]

193. Khorobrykh, S.; Havurinne, V.; Mattila, H.; Tyystjärvi, E. Oxygen and ROS in Photosynthesis. Plants 2020, 9, 91. [CrossRef] 
194. Turkan, I.; Uzilday, B.; Dietz, K.J.; Bräutigam, A.; Ozgur, R. Reactive oxygen species and redox regulation in mesophyll and bundle sheath cells of $C_{4}$ plants. J. Exp. Bot. 2018, 69, 3321-3331. [CrossRef]

195. Parida, A.K.; Das, A.B. Salt tolerance and salinity effects on plants: A review. Ecotox. Environ. Saf. 2005, 60, 324-349. [CrossRef]

196. Isayenkov, S.V.; Maathuis, J.M. Plant salinity stress: Many unanswered questions remain. Front. Plant Sci. 2019, 10, 80. [CrossRef] [PubMed] 